\title{
Crime investigation through DNA methylation analysis: methods and applications in forensics
}

\author{
Ajay Kumar Rana
}

\begin{abstract}
Discerning monozygotic twins, precisely predicting the age of human beings and most importantly interpreting human behavior remains a big challenge in forensic science. Modern advances in the field of epigenetics especially analysis of DNA methylation pattern can certainly help to identify and discriminate various single-source DNA samples such as bodily fluids collected from the crime scene. In this review, cytosine methylation analysis of DNA has been methodologically discussed with a broad range of applications in forensic science such as identifying single or mixed body fluid, discriminating monozygotic twins, age prediction, addiction/behavioral prediction as well as race/ethnicity identification. With the advances of next-generation sequencing techniques, blooming of DNA methylation datasets and together with standard epigenetic protocols, the prospect of investigating and solving these critical issues in forensic science is highly promising in the court of law.
\end{abstract}

Keywords: DNA Methylation, 5-methylcytosine, Differentially Methylated Regions, Cell Differentiation, Human Identification, Forensics

\section{Background}

Forensic biology often involves the study of challenging samples such as discriminating monozygotic twins, predicting age of human from its left over body tissue and distinguishing indiscernible body fluids/tissues whose identity determination remains a big challenge in the forensic laboratories. At the site of the crime, the body fluids of a human such as blood, semen, visceral fluid, vaginal fluid, saliva, or even menstrual fluid are washed out of its natural texture and are often mixed or discolored due to drying/bleaching out during a long exposure. Such obscure exhibits present a big challenge in front of forensic scientists to determine the actual cause/severity of the crime. The current method of DNA investigation in forensic laboratories is carried out by Identifiler ${ }^{\circ} /$ GlobalFiler $^{\circ}$ Express kits (Life Science Technology Ltd) (Hennessy et al., 2014; Mulero et al., 2008; Wang et al., 2012) or PowerPlex ${ }^{\oplus}$ kit (Promega) (Oostdik et al., 2014) or Investigator 24Plex kits (Qiagen) (Chen et al., 2010), which

Correspondence: ajay1rana@gmail.com

Division of Biology, State Forensic Science Laboratory, Ministry of Home Affairs, Government of Jharkhand, Near Birsa Munda Jail, Hotwar, Ranchi, Jharkhand 835217, India 
Apart from this, the other modifications of cytosine although minor are 5-hydroxymethylcytosine $(5 \mathrm{hmC}), 5$ formylcytosine $(5 \mathrm{fC})$ and 5-carboxycytosine $(5 \mathrm{caC})$ (Szulik et al., 2015) and all these modifications including $5 \mathrm{mC}$ are more often modulated either through cell-specific epigenetic expression pattern or environmental factors (Jaenisch \& Bird, 2003), psychological factors(Kim et al., 2016; Lam et al., 2012) or physical stress acting in and around the cells (Meaney \& Szyf, 2005; Unternaehrer et al., 2012).

A major part of DNA methylation pattern is lost while passing on from parents to their offspring; however, there is substantial epigenetic similarity that occurs between parents and offspring which actually recapitulate a parent's particular DNA methylation in the offspring which is known as epigenetic inheritance (Richards, 2006). These methyl groups in DNA are covalently introduced by enzymes called DNA methyltransferases (DNA MTases) according to the specificities of the DNA MTases which are in turn modulated by the environment (Fig. 1). The cofactor of the MTases, S-adenosyl-L-methionine (SAM) is used as the donor of the methyl group to methylate DNA at the specific position, most commonly pictured as palindromic sites (Auclair \& Weber, 2012; Jeltsch, 2002). Some of these methyl groups are removed by demethylases such as ten-eleven translocation (TET) proteins hence causing these methylation marks in the DNA to be reversible and dynamic in nature as per the cellular requirement and the environment (Auclair \& Weber, 2012) (Fig. 1). The field of molecular epigenetics is a swiftly developing area of research with a great emphasis on gene regulation, developmental biology as well as in therapeutic applications (Kalozoumi et al., 2012). The omnipresence of DNA methylation in almost all kingdoms of life and the distribution and diversity of DNA MTases in different species reflects their importance and vital cellular functions. 5methylcytosine and N6-methyladenine in the prokaryotic kingdom are fundamental for regulation of DNA replication, cell cycle, protecting DNA from restriction enzymes and conferring virulence to certain strains (Casadesus \& Low, 2006; Low et al., 2001; Ratel et al., 2006). As compared to the invertebrate kingdom, where the genome modification is less pronounced with a minor fraction of methylated DNA, the vertebrate's genome is modified with a diversity of nucleotide modifications (Deaton \& Bird, 2011; Koziol et al., 2016). In humans approximately $3 \%$ of the DNA is found to be $5 \mathrm{mC}$ methylated mostly at the CpG dinucleotides (Strachan \& Read, 2011) by the action of three major DNA methyltransferases viz. DNMT1, DNMT3a, DNMT3b (Moore et al., 2013) (Fig. 1a). Also, N6-methyladenosine in DNA (m6dA) has been recently discovered and identified in the nuclear genome of few vertebrates including human, mostly present in the intronic regions, which shows variations among the cell types (Koziol et al., 2016).
In humans, differentially methylated regions (DMRs) have been observed in chromosomal DNA, i.e. altered methylation patterns on same chromosomal DNA among different tissues or among individuals or others (Choufani et al., 2011). These DMRs observed among multiple tissues (tDMRs) of humans depicts a molecular view of epigenetic changes marked among different tissues. Forensic cases involving monozygotic twins study, tissues identification, human age determination or predicting his/her behavior are not possible to assort through STR profiling which is solely based on variation in DNA sequence repeats called short tandem repeats (Oostdik et al., 2014; Wang et al., 2012). On the other hand, methylation marks flagged in the DNA sequence is a result of cell type as well as its immediate environment (Marsit, 2015).

DMRs can be studied by many new emerging next generation sequencing (NGS) methods. NGS method supersedes the first generation sequencing method (chain termination method) which was introduced by Frederick Sanger, by incorporating two more dimensions in it viz. massively parallel sequencing and high throughput analysis (Mardis, 2013). Sanger method of DNA sequencing used ddNTPs as the chain terminators in addition to usual dNTPs in the ratio of 1:100 to sequence the phage $\phi X-174$ DNA (5,386 nucleotides) using polyacrylamide gel analysis (Sanger et al., 1977). In NGS method, sequencing of huge DNA such as of human ( $\sim 3$ billion nucleotides) can be carried out in a single day by synthesis of all the fragments of the genome so created using polymerase and labeling each nucleotide that is being incorporated. The problem only lies in the interpretation of the big data so generated.

Bisulfite conversion of genomic DNA and subsequently employing the next-generation sequencing (BSseq) is now a technique of choice to study the $5 \mathrm{mC}$ profile of the genomic DNA. $5 \mathrm{mC}$ profiling with the advent of NGS platform, Illumina (Masser et al., 2015) has provided a boost to the BS-seq method as well as led to the creation of many methylation databases (Grunau et al., 2001; Hackenberg et al., 2011). The detection of DNA methylation patterns is an advancing area of research in forensic science, which promises to distinguish various cell/tissue types (Zhang et al., 2013) or monozygotic twins (Levesque et al., 2014; Li et al., 2013), accurately estimate human age (Bekaert et al., 2015; Horvath, 2013), identify human bio-geographic/ethnicity type (Heyn et al., 2013; Xia et al., 1846) and can be applied to predict human behaviour as a new part of investigative forensic (Kockler et al., 2006; Kovatsi et al., 2011).

\section{Starting Forensic Samples, Collection Protocol and Storage}

Starting Forensic Samples

Except for the paternity dispute where blood samples or buccal swabs are collected without any contamination, 
a

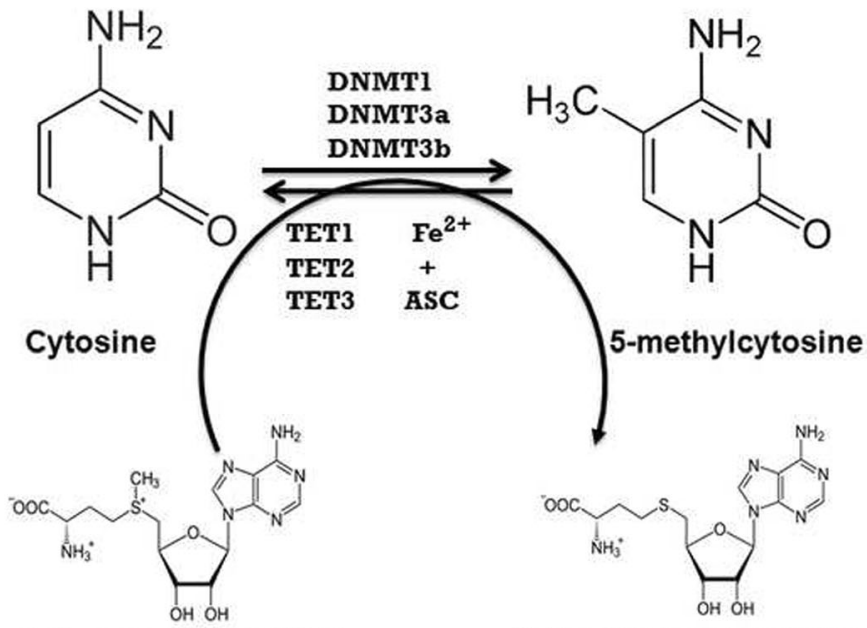

S-adenosyl-L-methionine (SAM)

S-adenosyl-L-homocysteine (SAH)
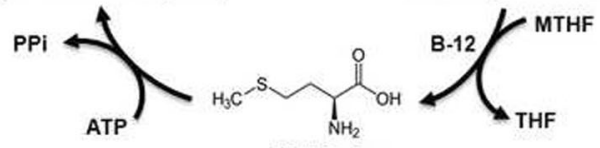

Methionine

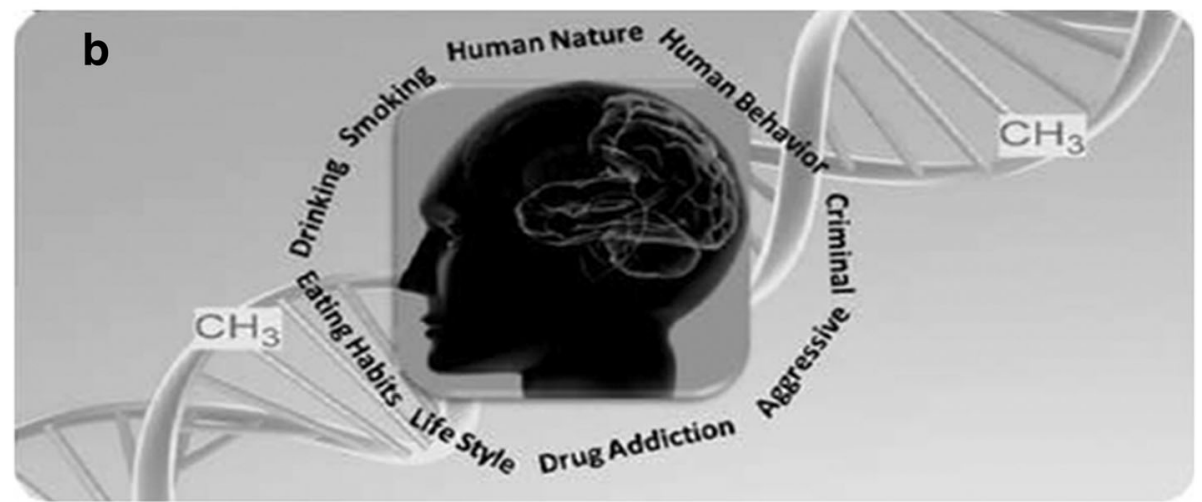

Fig. 1 DNA methylation dynamics and human phenotypic variations. a In humans, three different DNA methyltransferases (DNMT1, DNMT3a, and DNMT3b) are responsible for methylating the genomic DNA (primary substrate) at the $5^{\prime}$ position of the cytosine residue. The methyl group donor is S-adenosyl-L-methionine (SAM, also called cofactor or secondary substrate) which is oxidized to S-adenosyl-L-homocysteine (SAH) after donating the methyl group. In the genome, the methyl groups of cytosine residues are removed by ten-eleven translocation proteins (TET1, TET2, TET3) which use $\mathrm{Fe}^{2+}$ and ascorbate as additional cofactors. In a separate reaction system inside the cells, SAH is reduced to methionine using cofactor 5-methyl-tetrahydrofolate (MTHF), and the methionine is converted back to universal methyl donor SAM using an ATP molecule. b DNA methylation profile of human tissues/cells is affected by its immediate environment and activities such as lifestyle, eating habits, alcoholism, smoking, diseased, aggressive, drug addiction, perpetual criminal commitment, etc. The combined effect of the geographical location and the personal experiences/behaviors of individuals which are usually repetitive in nature leave behind certain methylation marks on their DNA

damage or deterioration, most of the biological samples collected from the crime scene legally known as exhibits are highly challenging to process in the forensic laboratory. Blood, blood stained objects, tissues, flesh, semen, vaginal swab from rape victim, hair, teeth, bone, saliva, epithelial cells, objects forcibly touched especially where body fluids/epithelial cells are left-over (for touch DNA analysis), bite marks on body, cigarette stubs, drinking bottles, toothbrush etc are some of the frequently observed and collected exhibits during investigation of a crime scene.

\section{Collection Protocol and Storage}

If it's a criminal case, then any body fluids found at the site other than on clothes are lifted on a sterile gauze piece with the help of sterile forceps. If the fluid is already dried at the crime scene then gauze piece/stain as such is first wetted in phosphate buffer saline (PBS) and then lifted with the help of forceps. The blood stains or non-blood biological stains are on victim/suspect cloths, or on small objects, then whole cloth/object as such is packed in a paper packet and finally in a cardboard box. If it's a civil case such as paternity dispute, 
then blood samples on gauze piece or buccal swabs on the cotton of toothpicks are collected. All the wet exhibits, are first dried preferably in shade, wrapped in brown paper which are then finally sealed and labelled in a paper envelope where collector (usually a forensic expert) puts his/her signature with date and time of collection. The bone piece (flesh removed), teeth or hairs are also wrapped in brown papers in dry condition and then sealed in a paper envelope/carton boxes. If the exhibit is flesh, then instantaneously it is put in sterile metallic container, packed with ice/dry ice or in liquid nitrogen if available, which is then immediately shipped to the forensic laboratory through proper channel. The sealed and signed samples collected from the forensic experts are handed to the Investigating Officer $(\mathrm{I} / \mathrm{O})$ of the case (generally a police officer in rank of subinspector (SI) or above) who from first to last through the proper chain of custody, forwards the exhibits to the State Forensic Laboratory through the Judge of Civil or Criminal Court as the case may be, bearing his/her majesty's seal and signature in the court's forwarding letter as well in the exhibit packet(s).

\section{Methods and Techniques of DNA methylation analysis}

A very sensitive as well as specific detection of $5 \mathrm{mC}$ methylation pattern on the DNA obtained from the questioned sample(s) is required to be devised to be followed routinely in a forensic laboratory. Although one of the easiest methods to detect and identify DNA methylation pattern is through the use of Illumina Infinium BeadChip array (the latest technology is the MethylationEPIC BeadChip (Moran et al., 2016)) which is nonetheless very expensive method to be used routinely in forensic analysis, however there are other molecular approaches and techniques which have been known for decades and some of them developed recently for detection and analysis of $5 \mathrm{mC}$ methylation pattern (Table 1). It should be noted that all these methods and analyses are based on either bisulfite treatment of DNA or use of methylation-sensitive restriction enzyme(s) or use of an antibody against the methylated base or a combination of them. These methods and techniques require certain amount of DNA in picogram (pg i.e. $10^{-}$ ${ }^{12} \mathrm{~g}$ ) or nanogram $\left(\mathrm{ng}\right.$ i.e. $10^{-9} \mathrm{~g}$ ) or microgram ( $\mu \mathrm{g}$ i.e. $10^{-6} \mathrm{~g}$ ), have different resolving power of methylation status in terms of bp and some are quite expensive and others relatively less expensive (Table 1 ).

\section{Bisulfite Sequencing and Methylation-Specific PCR (MSP)}

The treatment of DNA with sodium bisulfite $\left(\mathrm{Na}^{+} \mathrm{HSO}_{3}^{-}\right)$ converts unmethylated cytosines to uracils, while methylated cytosines are not affected (Darst et al., 2010). DNA is fragmented ( 200-800 bp) by sonication and is treated with bisulfite at lower $\mathrm{pH}(\mathrm{pH} 5)$ which adds sulfite group to the $\mathrm{C} 6$ of cytosine, which is then followed by incubating the samples at higher $\mathrm{pH}$, which removes sulfite group generating uracil. Methylated cytosine does not undergo bisulfite reaction due to steric hindrance exhibited by the methyl group. By performing simple PCR reaction and sequencing of the DNA, methylated and unmethylated cytosines of the DNA sequence are detected and determined (Fig. 2). An advanced method called bisulfite pyrosequencing is a quantitative method to determine the methylation status of individual $\mathrm{CpG}$ cytosines from PCR amplified products using unique sequencing-by-synthesis (SBS) method (Tost \& Gut, 2007) and can be used to distinguish various human body fluids (Madi et al., n.d.). The release of pyrophosphate (PPi) from the bisulfite treated DNA is proportional to the incorporation of dNTPs, which is converted into ATP to aid in subsequent conversions of luciferin to oxyluciferin. The quantitative portrait of the methylation profile for the amplicon in question can be used to distinguish many body fluids from its DNA obtained as low as $\sim 50 \mathrm{pg}$ (Vidaki et al., 2016).

Methylation Specific PCR (MSP) is a post-bisulfite treatment technique to discriminately amplify and detect a region of interest which mostly remains methylated using methylated-specific primers (Herman et al., 1996). The MSP method may also employ primer sets for unmethylated versions of the same sequence (Fig. 2). The later are useful as a control and sometimes to collect the positive data depending on the experiment. A related modified method called MethyLight MSP provides a quantitative analysis using quantitative real-time PCR (Eads et al., 2000), where methylated-specific primers containing fluorescence reporter anneals to the region of interest. An additional methodology which distinguishes MSP-generated DNA containing a low level of methylation is high resolution melting curve analysis (HRMA or Mc-MSP) (Kristensen et al., 2008; Wojdacz \& Dobrovic, 2009), which measures the quantitative ratio of methylated and unmethylated product as differing peaks so produced in the melting curve analysis.

\section{The COBRA Methylation Assay}

COBRA (Combined Bisulfite Restriction Analysis) methylation assay involves standard sodium bisulfite treatment of genomic DNA, followed by region-specific PCR amplification, purification of amplification products and restriction enzyme digestion (Fig. 2) and finally analysis of the results (Xiong \& Laird, 1997). It is highly specific, sequence-dependent and provides information regarding the methylation status of a DNA sequence. Bio-COBRA, an advanced chip-based assay, which includes an electrophoresis step (after restriction digestion) in microfluidics devices, where nanolitres of 
Table 1 Methods/techniques for detecting/analysis of Differential DNA methylation

\begin{tabular}{|c|c|c|c|c|c|c|c|}
\hline $\begin{array}{l}\text { S. } \\
\text { No. }\end{array}$ & $\begin{array}{l}\text { Methods/ } \\
\text { Techniques }\end{array}$ & $\begin{array}{l}\text { Quantity of human } \\
\text { DNA required }\end{array}$ & $\begin{array}{l}\text { Maximum } \\
\text { Resolution (bp) }\end{array}$ & $\begin{array}{l}\text { Gene } \\
\text { Specific }\end{array}$ & Epigenomic & Price $^{d}$ in USD & References \\
\hline 1. & $\begin{array}{l}\text { Bisulfite Sequencing (BS-Seq)/ } \\
\text { BS-Pyrosequencing/ } \\
\text { Whole Genome Bisulfite } \\
\text { Sequencing (WGBS) }\end{array}$ & $\begin{array}{l}30 \mathrm{ng} / 50 \mathrm{pg} / \\
2-5 \mu \mathrm{g}^{\mathrm{a}} \text { respectively }\end{array}$ & 1 & $\checkmark$ & $\checkmark$ & $\begin{array}{l}\$ 100+\$ 100-1000 \text { per test, } \\
\text { (DNA methylation analysis } \\
\text { kit from Thermo } \\
\text { Fisher Scientific) }\end{array}$ & $\begin{array}{l}\text { (Gu et al., 2010; Bibikova et al., } \\
\text { 2011; Antunes et al., 2016; Vidaki } \\
\text { et al., 2016) }\end{array}$ \\
\hline 2. & $\begin{array}{l}\text { Methyl Specific PCR (MSP)/ } \\
\text { MethylLight MSP/Mc-MSPa }\end{array}$ & $\begin{array}{l}100 \mathrm{pg} / 10 \mathrm{pg} / \mathrm{1-10} \\
\mu \mathrm{g} \text { respectively }\end{array}$ & 1 & $\checkmark$ & $x$ & $\begin{array}{l}\$ 100+\$ 100-300 \text { per test, } \\
\text { (DNA methylation analysis } \\
\text { kit from Thermo Fisher } \\
\text { Scientific) }\end{array}$ & $\begin{array}{l}\text { (Herman et al., 1996; Rand et al., } \\
\text { 2002; Kristensen et al., 2008; Lo et } \\
\text { al., 2009) }\end{array}$ \\
\hline 3. & $\begin{array}{l}\text { COBRA Methylation } \\
\text { Assay/ Bio-COBRA }^{\mathrm{b}}\end{array}$ & $\begin{array}{l}1 \mu \mathrm{g} / 20 \mathrm{ng} \\
\text { respectively }\end{array}$ & Not Applicable & $\checkmark$ & $x$ & $\begin{array}{l}\$ 100+\$ 100-200 \text { per test, } \\
\text { (DNA methylation analysis } \\
\text { kit from Thermo Fisher } \\
\text { Scientific) }\end{array}$ & $\begin{array}{l}\text { (Xiong and Laird, 1997; Brena et } \\
\text { al., 2006; Brena and Plass, 2009; } \\
\text { Yang et al., 2010) }\end{array}$ \\
\hline 4. & HELP Methylation Assay ${ }^{b}$ & $100 \mathrm{ng}-1 \mu \mathrm{g}$ & Not Applicable & $\checkmark$ & $\checkmark$ & $\begin{array}{l}\$ 100+\$ 200 \text { per test, } \\
\text { (Thermo Fisher Scientific, } \\
\text { New England Biolabs) }\end{array}$ & $\begin{array}{l}\text { (Khulan et al., 2006; Oda and } \\
\text { Greally, 2009; Shaknovich et al., } \\
\text { 2010) }\end{array}$ \\
\hline 5. & $\begin{array}{l}\text { Methylation-sensitive } \\
\text { Restriction Enzyme based } \\
\text { Microarray (MRE-Microarray) }\end{array}$ & $250 \mathrm{ng}-2 \mu \mathrm{g}$ & 1 & $\checkmark$ & $\checkmark$ & $\begin{array}{l}\$ 100+\$ 5,800-16 \text { tests, } \\
\text { EPIC array }\end{array}$ & (Fouse et al., 2010) \\
\hline 6. & $\begin{array}{l}\text { Illumina Infinium Methylation } \\
\text { Assay (Bead Array and } \\
\text { NGS Analysis) }\end{array}$ & $200 \mathrm{ng}-1 \mu \mathrm{g}$ & 1 & $x$ & $\checkmark$ & $\begin{array}{l}\$ 3,30012 \text { tests, EPIC library, } \\
\$ 5,80016 \text { tests, EPIC array }\end{array}$ & $\begin{array}{l}\text { (Bibikova et al., 2011; Thompson } \\
\text { et al., 2012; Touleimat and Tost, } \\
\text { 2012; McCartney et al., 2016; } \\
\text { Pidsley et al., 2016) }\end{array}$ \\
\hline 7. & $\begin{array}{l}\text { Methyl-CpG Binding } \\
\text { Domain Protein } \\
\text { Sequencing (MBD-Seq) }\end{array}$ & $5 \mathrm{ng}-1 \mu \mathrm{g}$ & 150 & $x$ & $\checkmark$ & $\begin{array}{l}\$ 550-48 \text { tests } \\
\text { (diagenode }^{\oplus} \text { ) }\end{array}$ & $\begin{array}{l}\text { (Fraga et al., 2003; Rauch and } \\
\text { Pfeifer, 2005; Lan et al., 2011; } \\
\text { Aberg et al., 2012) }\end{array}$ \\
\hline 8. & $\begin{array}{l}\text { Methylated DNA } \\
\text { Immunoprecipitation } \\
\text { (MeDIP) PCR/Sequencing }\end{array}$ & $120 \mathrm{ng}-1.0 \mu \mathrm{g}$ & 100 & $\checkmark$ & $\checkmark$ & $\begin{array}{l}\$ 390-24 \text { tests, } \$ 590-48 \\
\text { tests (abcam) }\end{array}$ & $\begin{array}{l}\text { (Mohn et al., 2009; Sorensen and } \\
\text { Collas, 2009; Borgel et al., 2012; } \\
\text { Taiwo et al., 2012; Zhao et al., } \\
\text { 2014; Staunstrup et al., 2016) }\end{array}$ \\
\hline 9. & $\begin{array}{l}\text { Methylation Analysis through } \\
\text { Single Base Extension (SBE) }\end{array}$ & $\begin{array}{l}0.5 \mathrm{ng} \text { to } 1.0 \mathrm{ng} \text { of gDNA } \\
\text { or } 1.0-5.0 \mathrm{ng} \text { of cloned } \\
\text { template DNA }\end{array}$ & 1 & $\checkmark$ & $x$ & $\begin{array}{l}\$ 840-100 \text { tests,(SNaPshot }{ }^{\mathrm{TM}} \\
\text { Multiplex Kit from } \\
\text { Thermo Fisher Scientific) }\end{array}$ & $\begin{array}{l}\text { (Kaminsky and Petronis, 2009; } \\
\text { Forat et al., 2016) }\end{array}$ \\
\hline
\end{tabular}

${ }^{a}$ Methods based on PCR/sequencing of bisulfite treated DNA

${ }^{b}$ Methods based on restriction digestion analysis

${ }^{c}$ Methods based on methyl-directed antibody or capture protein

${ }^{d}$ The prices are approximate obtained from Company websites in November 2017 for the specific kit only, excluding the associated costs such as infrastructure or cost to isolate DNA from the challenging exhibits.

reagents are run in miniaturized systems (Brena et al., 2006; Brena \& Plass, 2009). Specifically, Bio-COBRA is a high-throughput assessment of DNA methylation of large sample sets, very quickly and quantitatively.

\section{The HELP Methylation Assay}

The HELP (HpaII tiny fragment Enrichment by Ligationmediated PCR) assay is another technique used for determining the dynamic nature of methylation status of DNA from different cells/tissues or from same cells/tissues kept under different conditions (Oda \& Greally, 2009). Gene level, as well as genomic level of DNA methylation, is ascertained through this technique. It employs two restriction enzymes; HpaII, methylation-sensitive and MspI methylationinsensitive (isoschizomer), to digest the genomic DNA, contrast the digestion products generated by these enzymes and finally use ligation-mediated PCR (size range is limited from 200-2000 bp) (Khulan et al., 2006). HpaII specifically digests unmethylated 5'-CCGG-3' sites and enrich the methylation deficient regions of the genome. $5 \mathrm{mC}$ methylation state at each locus point is determined by comparing the representations made by HpaII as well as MspI (Shaknovich et al., 2010).

\section{Methylation-sensitive restriction enzyme based microarray (MRE- microarray)}

DNA with $5 \mathrm{mC}$ mark may be immune or non-immune to certain classes of restriction enzymes (Wilson \& Murray, 1991). This differential sensitivity of restriction enzyme towards DNA digestion can be utilized to approximate and map the cytosine methyl groups in forensic DNA exhibits and reference samples for comparison. The genomic DNA is fragmented ( $<200 \mathrm{bp}$ ) by using restriction enzyme MseI, which recognizes 5'TTAA-3' sequence, leaving most CpG islands (CGIs) intact (Yan et al., 2002). These digestion products are ligated to synthetic linkers and again restricted with BstUI and/or HpaII, since both are CpG specific and cover more than $90 \%$ of CGIs. The resulting DNAs obtained are amplified using linker-dependent PCR. The PCR products are then labeled with Cy3 (Em $\sim 570 \mathrm{~nm}$, greenish yellow) and Cy5 (Em 630 nm, red) dyes. In practical, Cy3 dye can be used for labeling the 


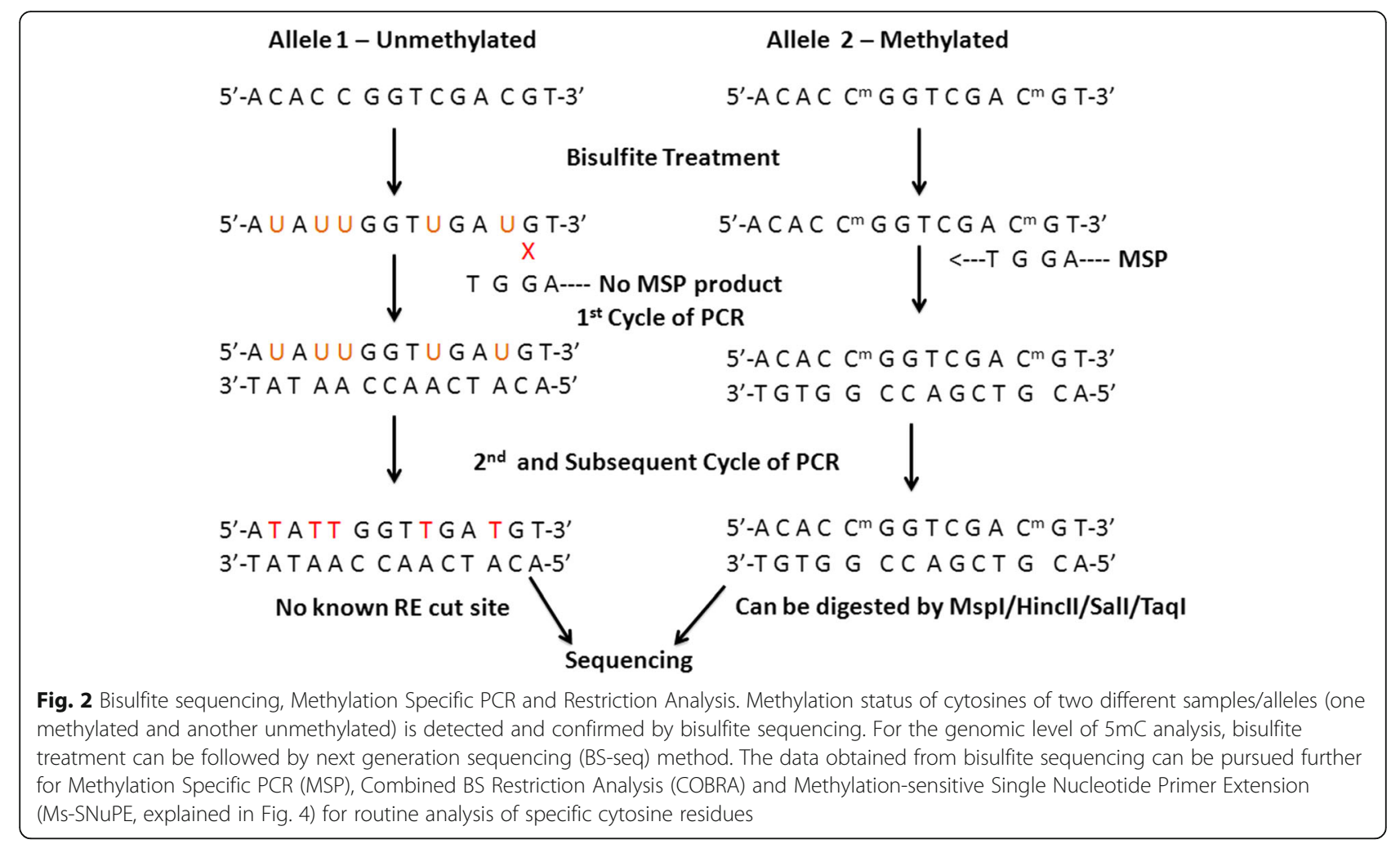

DNA obtained from a reference sample, while Cy5 dye can be used to label the DNA obtained from the site of the crime. These labeled products from both groups are mixed well in equal amount and blotted on differential methylation hybridization (DMH) microarray slide having printed human CGI library probes (Schumacher et al., 2006). After stringent washing, microarray slide is then subjected to fluorescence scanning. The intensity of Cy3/ Cy5 ratio at each locus here will reflect the methylation status in the reference DNA relative to that in the DNA obtained from the site of the crime.

\section{Illumina Infinium Methylation Assay}

Illumina's Infinium Methylation Assay is used to measure methylation level at the single-CpG-site and therefore can offer the highest resolution for identifying the various tissue types and solving many different forensic cases (Table 2). Illumina platforms can perform both bead array and NGS analyses. The recently outdated Illumina Infinium Human Methylation 450K BeadChip (Illumina Inc.), had the coverage of $>480,000 \mathrm{CpG}$ sites of the genome, which included $\sim 99 \%$ of RefSeq genes (Touleimat \& Tost, 2012). This technology has now been superseded by Infinium MethylationEPIC BeadChip microarray which covers > 850,000 methylation sites, including extra 333,265 CpG sites of enhancer regions made possible by ENCODE and FANTOM5 projects (McCartney et al., 2016; Moran et al., 2016; Pidsley et al., 2016). The methylation data of these CpG sites can be obtained from very low amount of genomic DNA ( 250 ng). The data is then transformed into genotypic differences that are quantitative analyzed (Cheng et al., 2014). After bisulfite treatment of genomic DNA as a usual standard protocol, the assay differentiates methylated versus non-methylated CpG sites using either Infinium I chemistry or Infinium II chemistry. In Infinium I chemistry, two different site-specific probes, $\mathrm{M}$ bead type and $\mathrm{U}$ bead type, each of 50 nucleotides terminates with an extension based fluorophore, directly at the methylated $\mathrm{C}(\mathrm{G}-\mathrm{Cy} 3)$ and unmethylated $\mathrm{C}(\mathrm{A}-\mathrm{Cy} 5)$ respectively. Infinium II chemistry utilizes 49 nucleotides single probe which on hybridization is extended by a single nucleotide containing either G-Cy3 for methylated or A-Cy5 for unmethylated. Quantitative value ( $\beta$-value) of DNA methylation for each CpG site is generated with the Illumina GenomeStudio software (Triche Jr et al., 2013).

\section{Methyl-CpG Binding Domain Protein Sequencing}

Methyl-CpG binding domain protein sequencing (MBDseq) is another technique which is used to determine genome-wide $5 \mathrm{mC}$ methylation patterns of humans (Aberg et al., 2012). In MBD-seq method, genomic DNA is fragmented and the methylated sequences are pulled down by a $5 \mathrm{mC}$ binding protein or simply using MethylMiner Methylated DNA Enrichment Kit (Invitrogen) (Harris et al., 2010). These methylated fragments are sequenced using high-throughput sequencing techniques (Lan et al., 2011; Rauch \& Pfeifer, 2005), and the exact 
Table 2 Forensic exhibits and some epigenetic markers (CpG) information available using Illumina Infinium HumanMethylation450 BeadChip array

\begin{tabular}{|c|c|c|c|c|c|}
\hline S. No. & Forensic exhibits & Gene & Map $\operatorname{lnfo}^{c}$ & CpG Target/Illumina ID ${ }^{c}$ & References \\
\hline \multirow[t]{4}{*}{1.} & Blood/MNC ${ }^{a}$ & $\begin{array}{l}\text { MAFG } \\
\text { SBNO2 } \\
\text { MYO1G } \\
\text { NCOR2 }\end{array}$ & $\begin{array}{l}\text { Chr17: } 79881543 \\
\text { Chr19: } 1155225 \\
\text { Chr7: } 45018849 \\
\text { Chr12: } 124950720\end{array}$ & $\begin{array}{l}\text { cg01543184 } \\
\text { cg06578434 } \\
\text { cg10673833 } \\
\text { cg25922751 }\end{array}$ & $\begin{array}{l}\text { (Thompson et al., 2012; Smith et al., 2014; } \\
\text { Benton et al., 2015; Lee et al., 2015) }\end{array}$ \\
\hline & Saliva/BEC ${ }^{b}$ & $\begin{array}{l}\text { DMRTA2 } \\
\text { BARX1 } \\
\text { HOXA3 } \\
\text { NFIX }\end{array}$ & $\begin{array}{l}\text { Chr1: } 50884480 \\
\text { Chr9: } 96715256 \\
\text { Chr7: } 27146262 \\
\text { Chr19: } 13112283\end{array}$ & $\begin{array}{l}\operatorname{cg} 10512745 \\
\text { cg13398482 } \\
\text { cg01964852 } \\
\text { cg22824635 }\end{array}$ & \\
\hline & $\begin{array}{l}\text { Vaginal Secretion/ } \\
\text { Menstrual Fluid }\end{array}$ & $\begin{array}{l}\text { HOXD9 } \\
\text { HOTAIR } \\
\text { C3 } \\
\text { SHANK3 }\end{array}$ & $\begin{array}{l}\text { Chr2: } 176988203 \\
\text { Chr12: } 54355528 \\
\text { Chr19: } 6721955 \\
\text { Chr22: } 51169500\end{array}$ & $\begin{array}{l}\operatorname{cg} 22541735 \\
\operatorname{cg} 26079753 \\
\operatorname{cg} 14279361 \\
\operatorname{cg} 06422471\end{array}$ & \\
\hline & Semen & $\begin{array}{l}\text { ACCN4;ASIC4 } \\
\text { PLEC;MIR661 } \\
\text { SARS } \\
\text { ANKAR } \\
\text { DACT1 } \\
\text { USP49 }\end{array}$ & $\begin{array}{l}\text { Chr2: } 220379058 \\
\text { Chr8: } 145018185 \\
\text { Chr1: } 109756023 \\
\text { Chr2: } 190540650 \\
\text { Chr14: } 59104243 \\
\text { Chr6: } 41862737\end{array}$ & $\begin{array}{l}\text { cg2 } 24743778 \\
\text { cg2 } 26763284 \\
\text { cg18346935 } \\
\text { cg05540789 } \\
\text { cg04216397 } \\
\text { cg01289140 }\end{array}$ & \\
\hline 2. & Monozygotic twins & $\begin{array}{l}\text { SLC6A4/SERT } \\
\text { MAOA } \\
\text { PTPN7 }\end{array}$ & $\begin{array}{l}\text { Chr17: } 28562220 \\
\text { ChrX: } 43515457 \\
\text { Chr1: } 202129566\end{array}$ & $\begin{array}{l}\operatorname{cg} 22584138 \\
\operatorname{cg} 14191108 \\
\operatorname{cg} 18384097\end{array}$ & $\begin{array}{l}\text { (Wong et al., 2010; Zhao et al., 2011; } \\
\text { Souren et al., 2013) }\end{array}$ \\
\hline 3. & Age & $\begin{array}{l}\text { CELF6 } \\
\text { NHLRC1 } \\
\text { EDARADD } \\
\text { ASPA } \\
\text { PDE4C } \\
\text { ELOVL2 }\end{array}$ & $\begin{array}{l}\text { Chr15: } 72612125 \\
\text { Chr6: } 18122719 \\
\text { Chr1: } 236559675 \\
\text { Chr17:3377265 } \\
\text { Chr19: } 18343901 \\
\text { Chr6: } 11043368\end{array}$ & $\begin{array}{l}\text { cg21801378 } \\
\text { cg222736354 } \\
\text { cg09809672 } \\
\text { cg02228185 } \\
\text { cg17861230 } \\
\text { cg01799681 }\end{array}$ & $\begin{array}{l}\text { (Bocklandt et al., 2011; Zykovich et al., 2013; } \\
\text { Bekaert et al., 2015; Jones et al., 2015; } \\
\text { Eipel et al., 2016) }\end{array}$ \\
\hline 4. & Race/Ethnic & $\begin{array}{l}\text { CD101; IGSF2 } \\
\text { PLSCR2 } \\
\text { KRTCAP3 } \\
\text { PM20D1 }\end{array}$ & $\begin{array}{l}\text { Chr1:117544416 } \\
\text { Chr3:146213845 } \\
\text { Chr 2: } 27665128 \\
\text { Chr1:205818956 }\end{array}$ & $\begin{array}{l}\text { cg2 } 23953831 \\
\text { cg15847988 } \\
\text { cg24768116 } \\
\text { cg17178900 }\end{array}$ & (Fraser et al., 2012; Heyn et al., 2013) \\
\hline 5. & $\begin{array}{l}\text { Smoking } \\
\text { Obesity } \\
\text { T2D } \\
\text { Pain }\end{array}$ & $\begin{array}{l}\text { AHRR } \\
\text { F2RL3 } \\
\text { PLIN4 } \\
\text { FTO } \\
\text { ADCY1 }\end{array}$ & $\begin{array}{l}\text { Chr5: } 373378 \\
\text { Chr19: } 17000585 \\
\text { Chr19: } 4517804 \\
\text { Chr16: } 53809231 \\
\text { Chr11: } 507970\end{array}$ & $\begin{array}{l}\text { cg05575921 } \\
\text { cg03636183 } \\
\text { cg01907005 } \\
\text { cg26580413 } \\
\text { cg06417962 }\end{array}$ & $\begin{array}{l}\text { (Breitling et al., 2011; Zeilinger et al., 2013; } \\
\text { Bell et al., 2014; Benton et al., 2015) }\end{array}$ \\
\hline
\end{tabular}

${ }^{\mathrm{a}}$ Mononuclear cells

${ }^{b}$ Buccal epithelial cells

'(Source: Infinium HumanMethylation450K v1.2 Product Files for

Beadchip, https://support.illumina.com/downloads/infinium_humanmethylation450_product_files.html)

position of sequenced tags is determined by comparing them to the human genome. The technique is quite effective for measurement of methylation status of CpG islands containing high density of $\mathrm{CpG}$ sites (Fraga et al., 2003).

\section{Methylated DNA Immunoprecipitation PCR/Sequencing (MeDIP-PCR/seq)}

Methylated DNA Immunoprecipitation (MeDIP) involves pulling down methylated DNA regions of the genome using an antibody raised $5 \mathrm{mC}$ (Borgel et al., 2012; Mohn et al., 2009). Conventionally a Dot blot method (Clement \& Benhattar, 2005) can be performed with the direct addition of $5 \mathrm{mC}$ antibody on the fragmented DNA immobilized on Nylon membrane and intensity measurement of fluorescent secondary antibody provides the information of the presence, absence or amount of methyl groups roughly present in a given DNA sample (Fig. 3) (Koziol et al., 2016). MeDIP is an efficient technique for the extraction of methylated DNA from forensic human samples which can include blood, bone and hair samples of commonly used as exhibits. DNA immunoprecipitation combined with next generation sequencing methods termed as MeDIPseq can be used to for the generation of methylomes from tissue or cells using 160-300 ng of starting DNA (Taiwo et al., 2012). Briefly, the genomic DNA is sonicated to obtain fragments (200-800 bp) and immunoprecipitated with monoclonal antibodies raised against 5-methylcytidine (much like methyl capture protein in MBD-seq method). Antibody-Methylated DNA complex is then purified using paramagnetic beads that isolate it from the rest of non$5 \mathrm{mC}$ methylated/unspecific DNA. The methylated DNA 


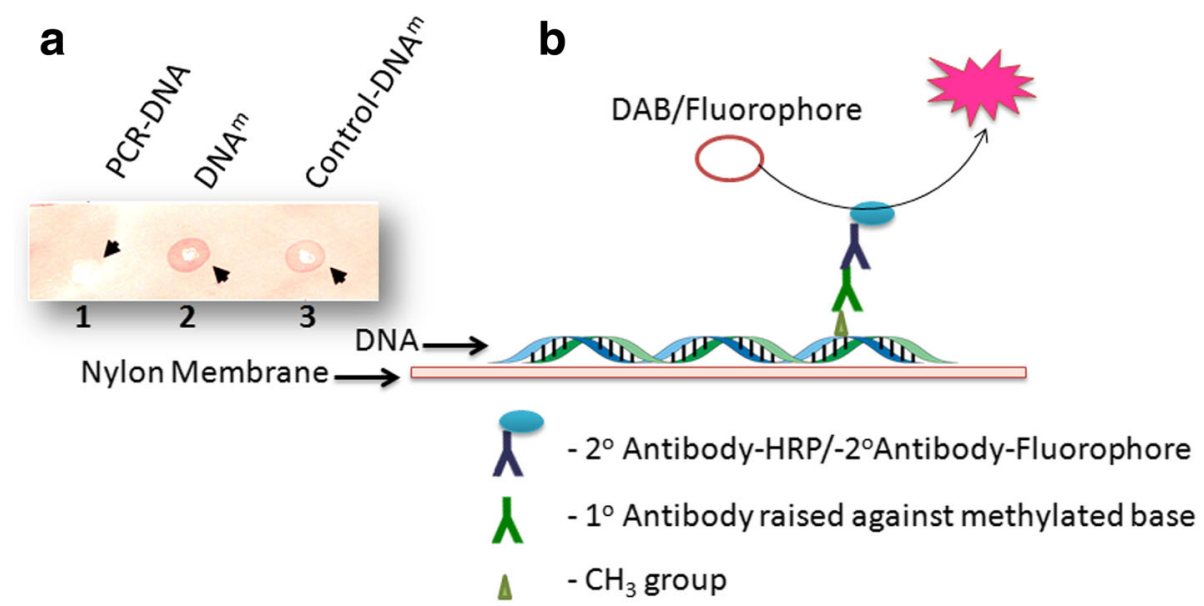

Fig. 3 DNA methylation detection through Immuno-precipitation (Dot-blot method). a. The methylated DNA (dot 2 and 3) develops color precipitate/fluorescence while unmethylated DNA (dot 1) fails to develop the color/fluorescence in the nylon blot. b. The DNA is spotted as a dot in the nylon membrane and then primary antibody is blotted, which is followed by a secondary antibody conjugated with horse radish peroxidase enzyme. The addition of enzyme's substrate such as 3'-3' diamino benzidine (DAB) produces a pink precipitate. Alternatively, a fluorophore-tagged secondary antibody (Alexa Fluor Ab) can be used to visualize the presence of methyl group

so obtained can be used for MSP, methylation-sensitive restriction enzyme analysis or genome-wide $5 \mathrm{mC}$ analysis through sequencing/microarray (Borgel et al., 2012). In the genomic analysis of methylated DNA, the fragments of 36-50 bp or $400 \mathrm{bp}$, as per the method used, with methylated reads are produced. Using a visual browser such as Ensembl, these methylated reads (sequences) are aligned and compared to the human genome using alignment software such as MeQA (http://life.tongji.edu.cn/meqa/) (Huang et al., 2012). MeDIP-PCRs targets methylated genomic loci with starting genomic DNA as low as $\sim 1 \mathrm{ng}$ (Zhao et al., 2014) which could be highly useful for methylation profiling of challenging DNA samples in forensics.

\section{Methylation analysis through Single Base Extension}

Single-base extension (SBE) is a method to identify a singlenucleotide polymorphism (SNP) for determining the identity of a nucleotide base at a specific position along a nucleic acid (Hu \& Zhang, 2012). It involves hybridization of an oligonucleotide probe to a complementary region of the nucleic acid, with the probe's 3 ' end terminal directly adjacent to the nucleotide base to be identified. The probe is enzymatically extended a single base with a nucleotide terminator, 2',3'dideoxynucleotide triphosphate (ddNTP) which base pair (bp) to the nucleotide in question (Fig. 4). The terminator does not allow further extension of the sequence. The terminator base can be identified using fluorescence labeling, isotope labeling, mass labeling for mass spectrometry and measuring enzymatic activity using an enzyme conjugate.

Single base extension of primers using a fluorescently labeled ddNTP terminator, originally commercialized as SNaPshot $^{\circ}$ (ABI PRISM SNaPshot Multiplex kit) by Life technologies for analytical analysis of cytosine methylation status of CpG rich genomic DNA by capillary electrophoresis (CE) has been successfully applied to bisulfite treated and PCR-amplified genomic DNA (Boyd \& Zon, 2008). The results can be analyzed using 310, 3100, 3500 and 3730 Genetic Analyzers (Life Technologies) and GeneMapper software of version $>3.1$ and displayed much like STR peaks in methylation $\mathrm{SNaPshot}$ as electropherogram except the former shows variation in repeat units and the latter in methylation status (Wnuk et al., 2013). The forensic exhibits containing DNA samples as listed in Table 2 can be successfully applied to SNaPshot multiplexing system using primers designed against the CPG site/lllumina ID of the known DNA sequence.

\section{Applications of DNA methylation in Forensic Science \\ Forensic DNA samples Authentication}

Scientists in Israel have demonstrated that DNA evidence may be fabricated (Link) using DNA that has been generated/amplified using standard molecular biology protocols such as in vitro PCR, in vivo molecular cloning in bacteria/yeast, and a decade ago developed whole genome amplification (WGA) technique, which practically enables anyone to synthesize large amount of DNA of any human being with any desired STR profile containing 13/15/23 loci + Amelogenin recommended by FBI, USA. The artificial DNA can be planted in and around crime scenes or applied to nearby objects or enmeshed with genuine human tissues (Frumkin et al., 2010; Melchior et al., 2008). To resolve the issue and authenticate the forensic DNA samples, sodium bisulfite treatment of DNA, followed by MSP or cloning and Sanger sequencing can be carried 


\section{a \\ G G TACATGACACT G CT C C A T G T A C A G T G A C C ${ }^{m} G$ G Methylated Marker-1 \\ T CGAACT C CG T .GCATAGCTT GAGGCCA C ${ }^{\mathrm{A}} \mathrm{A} T$ Methylated Marker-2 \\ CTTCATAGTAC ACTTCGAAGTATCATG Cm A C. Methylated Marker-3}

b
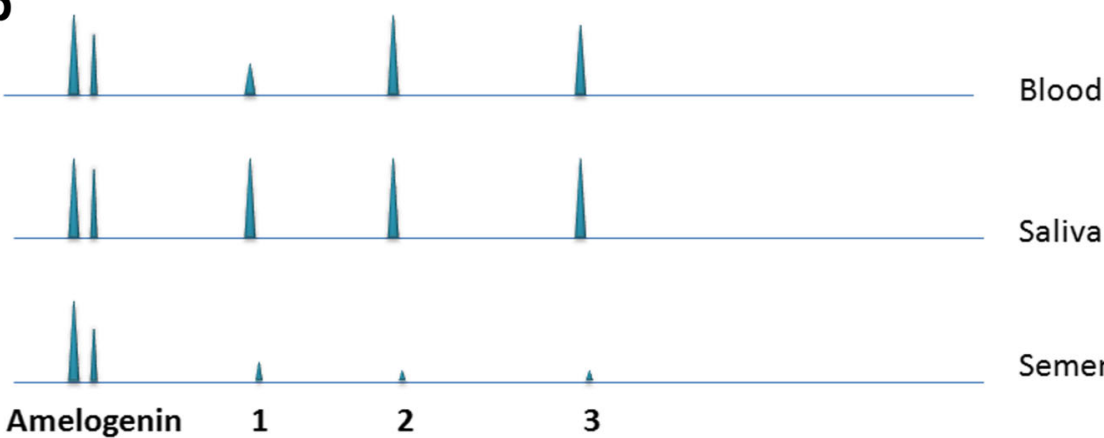

Semen

Fig. 4 Schematic representation of Methyl-sensitive Single Nucleotide Primer Extension (Ms-SNuPE) method. a This method can be used to detect cytosine methylation by designing primers of different lengths corresponding to different cytosine markers that vary among body fluids/tissues of human (e.g. blood, saliva, and semen) or between monozygotic twins or with the ageing of human beings. The primers are extended a single base with fluorescently labeled terminators (ddNTPs-Fluorophore) using DNA polymerase $\mathbf{b}$ The extended primers are then detected by running these products through the genetic analyzer (capillary electrophoresis)

out, which distinguishes the in vitro generated DNA versus genuine DNA (Frumkin et al., 2010).

\section{Age prediction of a person}

Age determination of victims and/or suspects is an important part of crime investigation and is of vital interest to a forensic scientist. The current approach of age determination which is based on an assessment of bone and teeth structure and composition is practically vague, rather methylation marks on the DNA obtained from these hard tissues can be used to accurately predict the chronological age of individuals (Bekaert et al., 2015; Giuliani et al., 2015). DNA methylation has an inheritable effect with age acceleration and is close to zero at the embryonic stage of an individual (Guo et al., 2014; Horvath, 2013). The age acceleration starts with a high degree of correlation in genomic DNA methylation marks in a broad range of human tissues and cells and is influenced by gender, genetic makeup (Hannum et al., 2012), racial (Kader \& Ghai, 2016; Park et al., 2016), clinical as well as lifestyle of an individual (Weidner et al., 2014). The human genomic regions have been identified with age-sensitive DNA methylation patterns (Yi et al., 2015), which helps in prediction of biological age as accurate as within 5 years of chronological age. The CpG methylation patterns in the promoter regions of the three genes viz. EDARADD, TOM1L1, and NPTX2 were shown to vary linearly (EDAR$A D D$ and NPTX2 are hypomethylated while TOM1L1 is hypermethylated) with increasing age among 18 - 70 year of individuals (Bocklandt et al., 2011). In further studies, five genes (NPTX2, TRIM58, GRIA2, KCNQ1DN and BIRC4BP) have been shown to continuously shed off methyl group (hypomethylated) with increasing age in various human tissues (Koch \& Wagner, 2011) while the gene ELOVL2 showed increasing methylation level with aging (Garagnani et al., 2012). ELOVL2 methylation marks in human blood samples are very stable and do not change significantly over a month period and are up to $70 \%$ preserved in a decade old sample which grades it highly powerful in age prediction of blood exhibits in forensic science (Zbiec-Piekarska et al., 2014). Further researches in concert have developed the epigenetic markers (cg06304190, cg06979108, and cg12837463) for age prediction using semen samples (Lee et al., 2015). In an another research work, some of the CpG DNA methylation loci (ASPA, PDE4C, ELOVL2, FHL2, CCDC102B, C1orf132, chr16:85395429 and EDARADD) have been used to predict accurately the age of deceased or live individuals using their blood samples (Bekaert et al., 2015; Freire-Aradas et al., 2016). Beside accurate age prediction, DNA 
methylation can also help to measure the rate of aging (Horvath, 2013). In physically and healthily compromised individuals, deviation from normal aging rate may be observed. Human aging-associated differentially methylated regions (aDMRs) in the human genome occur in almost all tissues and cells (except spermatozoa) as hyperaDMRs, preferentially at the developmental gene promoters (Rakyan et al., 2010). DNA methylation signatures in the prefrontal cortex of human can also be used to precisely estimate the aging rate or age of a human sample (Numata et al., 2012). The age analysis can be performed at: https://dnamage.genetics.ucla.edu/

The CpG methylation data obtained from Illumina DNA Infinium of a forensic sample can be uploaded to the above online software to invariably calculate the precise age of the questioned sample. As an alternative method, generation of methylation sensitive HRMA can be carried out using the promoter regions of ELOVL2 and FHL2 loci to predict the age of an individual (Hamano et al., 2016).

\section{Sources of tissue/body fluid identification}

Identifying and establishing the source of tissue from the site of crime would be helpful in recreating the crime scene (An et al., 2012). Some of the $5 \mathrm{mC}$ methylation marks in DNA are highly tissue specific (Table 2) and can be used to discriminate the origins of the DNA sample, either from a single source or multiple sources of the individual (Frumkin et al., 2011). It implies that when DNA is obtained from a mixture of bodily fluid, this technique would be able to discriminate it into semen, saliva, blood, or any other body tissues as per the methylation pattern (what can be termed as Next Generation Serology) (Park et al., 2014). It was Frumkin et al., who pioneered to explore and establish the $5 \mathrm{mC}$ based forensic tissue typing by incubating $\sim 1 \mathrm{ng}$ of DNA with methylation-sensitive restriction enzyme (Hhal, recognition site -GCGC-) while screening 38 genomic loci (205 CpG islands), where differential amplification patterns were obtained based on -GCGC- site methylation level (Frumkin et al., 2010). In another seminal work, it was shown that $5 \mathrm{mC}$ methylation pattern of the genes viz. DACT1, USP49, HOXA4, PFN3, and PRMT2 produced by bisulfite sequencing, could be used to distinguish blood, saliva, semen, menstrual blood, and vaginal fluid (Lee et al., 2012). In semen sample, DACT1 and USP49 are specifically hypomethylated, while in other body fluid HOXA4, PFN3, and PRMT2 show their characteristic methylation profile. Similarly to distinguish vaginal epithelia from other body fluids of forensic interests (blood, saliva, and semen), a recent study using bisulfite-modified pyrosequencing has established PFN3A as the novel marker (Antunes et al., 2016). In parallel a confirmatory test (multiplex methylation SNaPshot) for body fluid identification has been devised using 9 CpG menstrual blood markers which can specifically identify blood, saliva, semen, vaginal fluid and menstrual blood (Lee et al., 2016). The stability of these methylation markers in trace amounts of various body fluids may be marred by both endogenous and exogenous factors, and therefore a study using a large number of samples (100 for each body fluid) were performed using Illumina BeadChip Array, which showed comparable sensitivity of the results to STR analysis (Forat et al., 2016). The methylation pattern differences in the DNA of these various body fluids has been recently utilized to develop another novel forensic technique based on combined use of COBRA and MSP methods (Lin et al., 2016).

\section{Discerning monozygotic twins}

Monozygotic (MZ) twins having phenotypic differences subtle or otherwise carry exactly the same DNA sequence (concordant) throughout the genome they inherit and hence puts a roadblock to their identification using conventional STR, SNP, or mtDNA profiling (Chatterjee \& Morison, 2011). However, it has been observed that there is considerable variation in DNA methylation pattern between MZ twins which largely results from genetic lineage/makeup, pre- and post natal environmental conditions (Segal et al., 2016). Due to this epigenetic (DNA methylation) difference between monozygotic twins, these are known as discordant MZ twins with striking difference in susceptibility for various diseases (Castillo-Fernandez et al., 2014; Elboudwarej et al., 2016; Ribel-Madsen et al., 2012; Roos et al., 2016). Also, for male MZ pairs and female MZ pairs, there are marked differences of the $\mathrm{CPG}$ methylation level that are present at the autosomal or the X-chromosomal DNA (Watanabe et al., 2016). These differences in $5 \mathrm{mC}$ pattern can be identified by ultra-deep NGS as described by WeberLehmann et al. suggesting a solution to paternity and forensic cases involving MZ twins (Weber-Lehmann et al., 2014). Apart from sequencing, HRMA experiment can be performed using bisulfite-converted/PCR-amplified DNA from both the twin's when one of the twin's DNA sequences having a greater number of methyl groups will show a different melting temperature (Stewart et al., 2015).

\section{Bio-geographic/Ethnic classification}

A large number of bio-geographic/ethnic diversities exists in the human population with having unique and different biogeographic distribution. Cases related to their native origin or migrated have been widely reported in the criminal justice system and their identity can be labeled using their unique methylation profile (Race \& Genetics Working Group, 2005; Royal et al., 2010). Differences in DNA methylation patterns among different human races are present right from the birth (Adkins et al., 2011) and these differences persist for generations as long as they maximally inhabit in the same biogeographic region. Methylation differences play an unambiguous role in imparting human phenotypic appearances (Heyn et al., 2013; Xia 
et al., 1846) as well as human behaviors and undeniably carry along with it certain human inherent characters including susceptibility to diseases such as diabetes and cancers (Mitchell \& Grant, 2015; Xia et al., 1846) (Fig. 1b). A few DNA methylation studies of different human races have been carried out recently, which reveal a distinct pattern of CpG methylation at a certain locus in the autosomal DNA (Table 2). Europeans DNA at AHRR locus are hypomethylated and South Asians have heavily methylated locus essentially due to differences in smoking trends (Europeans are heavy smokers) (Elliott et al., 2014). Tobacco smoking, in fact, contributes to global perturbation in the DNA methylome of human genome (Zeilinger et al., 2013). Also, African-Americans and Caucasian-Americans display $13.7 \%$ difference among autosomal CpGs patterns, even among the individuals carrying cancer (Adkins et al., 2011). These differences in cytosine methylation profile proffer a strong support to defend the forensic cases related to racial or ethnic disparities.

\section{Anti-social and aggressive behavior identification}

Criminal behavior, especially chronic one or repetitive anti-social behavior, has been known since long to be genetic (Carey \& Gottesman, 2006; Dinwiddie, 1996; Mednick \& Finello, 1983) but recent research trends classify it properly to be epigenetic and to be early environmentally predisposed (Fig. 1b) (Day \& Sweatt, 2010; Kovatsi et al., 2011; Provencal et al., 2014; Roth \& Sweatt, 2010). The epigenetic factor, especially DNA methylation is the most important aspect of behavioral disorders with marked alteration in the DNA methylation pattern in the brain which leads to memory formation (Day \& Sweatt, 2010). Early-life exposures to stress especially during pregnancy, humiliation or misleading parenting can alter normal epigenetic programming in the brain, with overwhelming consequences for gene expression and behavior (Khulan et al., 2014; Szyf, 2011; Wu et al., 2014). Recent studies have demonstrated an association between drug or beverage addiction of mothers with DNA methylation changes, a phenomenon that can mediate long-term alterations in gene expression (Kovatsi et al., 2011; Marjonen et al., 2015; Masemola et al., 2015; Philibert et al., 2012; Zhang et al., 2012). Even smoking addiction has a very sharp effect on DNA methylation pattern among South Asians and Europeans as explained in Section 3.5 with reference to AHRR locus (Elliott et al., 2014; Monick et al., 2012). Another important marker associated with smoking is cg03636183 (F2RL3) which is again hypomethylated among the smokers (Breitling et al., 2011). These smoking associated DNA methylation marks carry the risk of various cancers including blood, breast, colon and lung cancers (Monick et al., 2012; Shenker et al., 2013) and pass on from one generation to the next as an epigenetic memory (Day \& Sweatt, 2010) and it may sometimes take generations to mitigate the effect through rehabilitation or changing behavior/phenotype (Bouwland-Both et al., 2015). It can be concluded here that alcoholism, smoking, drug addiction or any other recurring longterm behavior impugn certain methylation marks on the human genomic DNA (Table 2) and can be used to designate an individual with such addiction/behavior to deal with relevant civil or criminal cases in the court of law. Moreover all smokers/alcoholic are not bound to commit a crime or are criminals, neither all non-smokers/ non-alcoholic are innocent, but likelihood of a smoker/ alcoholic to be an offender (a psychopathic phenotype(Tamatea, 2015)) has been correlated positively (> 90\%) in a study (Shareck \& Ellaway, 2011) as a record made by the police during criminal detention or alternatively perceived by their neighbouring residents.

\section{Conclusions}

The field of epigenetics has recently made a landmark entry in the research of forensic sciences as it has a high significance in critical identification and analysis of forensic samples which otherwise contain exactly the same DNA sequences. DNA methylation particularly cytosine methylation at the $\mathrm{CpG}$ sites, the major epigenetic and chemical change in the DNA (Jin et al., 2011) which without altering the DNA sequence leads to phenotypic variation among the various tissues, monozygotic twins or among humans has provided a new vista to distinguish cell types or tissues (Brunner et al., 2009; Lokk et al., 2014), monozygotic twins (Fraga et al., 2005; Heyn et al., 2013; Kaminsky et al., 2009), age of humans (Bekaert et al., 2015; Horvath, 2013; Yi et al., 2015), human races (Adkins et al., 2011; Heyn et al., 2013) or even can be used to predict certain criminal behaviours (Day \& Sweatt, 2010; Szyf, 2011; Szyf, 2013).

The epigenetic markers present in the DNA of human cells or tissues can be used to distinguish the different tissues of same the human being, discern monozygotic twins, identify human races, predict human behaviour as well as to accurately determine the age of a DNA donor (Bekaert et al., 2015) using whole-genome bisulfite sequencing using Illumina Infinium BeadChip array (McCartney et al., 2016; Moran et al., 2016; Touleimat \& Tost, 2012), or methylated DNA immunoprecipitation sequencing (Borgel et al., 2012; Cheung et al., 2011; Mohn et al., 2009; Pelizzola \& Molinaro, 2011; Sorensen \& Collas, 2009; Taiwo et al., 2012; Zhao et al., 2014) as discussed above. Interestingly, when micro-volume blood stain, saliva laden cigarette stubs or few fallen hair strands are recovered from the crime scene, extremely low amounts of DNA $(\leq 100 \mathrm{pg})$ as in the forensic case reported from Jharkhand (Rana et al., 2016), can be treated with bisulfite and then subjected to genome- 
wide amplification (Bundo et al., 2012), followed by quantitative methylation detection using the above technologies. The above methods have been found to produce comparable methylation results, but differ in $\mathrm{CpG}$ coverage, resolution, quantitative accuracy, efficiency, and cost. These methods also differ in their capability to detect and discriminate $\mathrm{CpG}$ as well as non-CpG methylation sites and the results show variation from one laboratory to another (Jung et al., 2016). Currently, the most advanced current array technology, Infinium MethylationEPIC BeadChip array, offers a unique, logistic and holistic approach, allowing assessment of the methylation status of not only $5 \mathrm{mC}$ but also $5 \mathrm{hmC}$, including 2880 CNG sites (where $\mathrm{N}$ is any nucleotide and $\mathrm{C}$ and $\mathrm{G}$ are cytosine and guanine) and 59 SNP sites (Moran et al., 2016). While the Infinium MethylationEPIC BeadChip Array methylation site coverage is quite large, it is still eclipsed by NGS technology when comparing genome coverage and flexibility (NGS will sequence virtually anything and is not restricted to a defined array, although NGS is still more expensive). The use of NGS methods lies in the fact that the methylation reads of the sequence can be used in the mapping of epigenetic variation (among tissues, twins or with the ageing of human being), which can be routinely applied to solve the forensic cases. NGS technology can be successfully exploited in the domain of forensic field by analyzing multiple loci simultaneously of forensic samples from autosomal DNA or sex chromosomes or mitochondrial DNA.

As far as mitochondrial DNA (mtDNA) is concerned, SNP analysis has immense importance in forensic investigation to delineate maternity as well as the ethnicity of an individual in question (Coble et al., 2004; Just et al., 2009). Other than the sequence variability, there are regions of unique methylation patterns that tend to vary among different tissues of an individual (Liu et al., 2016) as well as certain DNA regions where methylation variation can be observed among distantly related individuals. Since the discovery of mtDNA methylation way back in 1977 in animals (Vanyushin \& Kirnos, 1977), quantitative and qualitative analyses of mtDNA 5-methylcytosine $(5 \mathrm{mC})$ of human from three different sources of tissues viz. blood, saliva, and lung have been recently reported (Liu et al., 2016). Also, N6-methyladenosine in DNA (m6dA), a modification previously thought to be present only in prokaryotic DNA, has been recently discovered and identified in the nuclear genome of few vertebrates including human, mostly present in the intronic regions, which shows variations among the cell types (Koziol et al., 2016). We believe that mitochondria having prokaryotic in its origin must have m6dA modifications preserved in its DNA. The human mtDNA contains both CpG as well as non-CpG methylation patterns (Barres et al., 2009; Bellizzi et al.,
2013; Liu et al., 2016). No further work or exploration has been done for mitochondrial m6dA analysis, which is completely an unexplored as well as an exciting field to embark on. Human mitochondrial DNA is smaller in size (16569 bp) in comparison to nuclear DNA $\left(\sim 3 \times 10^{9} \mathrm{bp}\right)$, present in high copy number per cell $\left(\sim 10^{3}-10^{4}\right.$, nearly 10 copies is preset in each of the tens of hundreds of mitochondria per cell) (Lightowlers et al., 1997) and having intact and preserved DNA in double membranous structure, even in the dead and massively destroyed tissues (Barta et al., 2014; Higgins et al., 2015; Nesheva, 2015; Ozga et al., 2016; Schwarz et al., 2009), it has therefore clear advantages over nuclear DNA to be providentially recovered and easily manipulated from the questioned samples referred to the forensic laboratories.

The most remarkable outlook that this review is trying to represent here for the first time is the potential application of DNA methylation profiling to identify the human biogeographic type (racial), ancestry and phenotypic type (ethnicity), or certain criminal behaviour which may aid in gathering unseen (abstract) indirect evidences for some critical forensic cases. The assortment of behavioral evidence is today a part of well-known forensic discipline called 'investigative forensics' involving direct questioning from the suspects/ criminals and therefore interestingly this current molecular epigenetic approach of the behavioral study and the investigative forensics/psychological study are concluding at the same end but with entirely different fields of analysis. The current research in DNA phenotyping (physical appearance because of the unique DNA) shows that 24 DNA markers (SNP) can be successfully used to predict the color of the hair as well as the eye of an individual from the DNA obtained from his/her body tissues (Walsh et al., 2013). Other genes responsible for skin color, hair structure, and baldness have been determined (Hart et al., 2013; Liu et al., 2015; Marcinska et al., 2015; Pospiech et al., 2015). In future, this technique can be combined with predicting method of age, biogeographic/ethnicity as well as behaviour of an individual from the DNA methylation data (Next Generation DNA Phenotyping), which can be used to accurately construct the inclusive facial picture who leaves behind the DNA mark but has no match for his/her DNA fingerprint.

The research field of behavioral epigenetics is still in infancy today, similar to cancer genetics 50 years ago. The reproducibility of differential methylation pattern for many of these human conditions, especially neuropsychology disorders such as addiction and mental health, and the relationship between DNA methylation and altered gene expression and physiology, is required to be systematically analyzed. The epigenome expressed by human behavior is dynamic in nature and is 
modulated by many internal as well as external factors such as embryonic/human developmental, health issues if any and external environmental. This is why epigenome data interpretation is more challenging than genomic data. Not least, the challenge of eliminating library contamination, error rates of the enzymes used for DNA amplification as well as minimum insert size, adapter and hybridization artifacts etc has to be taken into account while considering epigenome sequencing. These are some of the major issues that may arise but have been rarely addressed by the various consortia under the shade of the International Human Epigenome Consortium (http://ihec-epigenomes.org/) that are decoding many tissues/cells specific epigenetic map from healthy donors as well as from diseased ones.

It is important to note that many of the above methods/techniques use only sodium bisulfite treatment and not glucosylation and thus cannot distinguish between 5-methylcytosine and the more abundant 5hydoxymethylation marks (5-hmC marks are often protected by glucosylation in vivo). Thus more research needs to be carried out and we are clearly not at the stage of scientific certainty to use information about the human epigenome to solve a case in a court of law. The various methods documented here are not intended for exhaustive solutions for identification of forensic tissues, monozygotic twins, age determination of person from cells/tissue, authentication of DNA, etc. rather one or more of these methods can be selected based on the case profile, suitability of the forensic exhibits/samples in hand, or depending on the accessibility of the instrument/resource as required in each experimental method. The use of DNA methylation in forensic analysis is still a risky task considering the amount of genomic DNA obtained from the exhibit in some challenging cases, the sensitivity of the antibody in hand against $5 \mathrm{mC}$, the suitability of the marker (DNA sequence) selected for PCR amplification and the detection methods/instrument used in the analysis. Despite these thwarting circumstances, advancement of methylation research and providing relevant training facilities to the forensic personnel can certainly overcome the above limitations producing enough expertise to introduce these sophisticated molecular techniques in very near future. The beginning of DNA methylation studies in forensic science is fundamental to support the conventional STR profiling and it is quite evident that in near future this technique may be utilized to produce independent evidence as well as corroborative evidence to detect, map and solve an array of forensic cases.

\section{Abbreviations}

5mC: 5-methylcytosine; aDMRs: Ageing associated differentially methylated regions; Beadchip: Bead chromatin immunoprecipitation; BS-seq: Bisulfite next generation sequencing; COBRA: Combined bisulfite restriction analysis;
CpG: Cytosine-phosphate-guanine; ddNTPs: Dideoxynucleotide triphosphate; DMH: Differential methylation hybridization; DMRs: Differentially methylated regions; dNTPs: Deoxynucleotide triphosphate; IP: Immunoprecipitation; MBD-seq: Methyl-CpG binding domain protein sequencing; MeDIP: Methylated DNA immunoprecipitation; MRE-microarray: Methylation sensitive restriction enzyme based - microarray; MSP: Methylation specific PCR; NGS: Next generation sequencing; SAM: S-adenosyl-L-Methionine; SBE: Single base extension; SBS: Sequencing by synthesis; SNP: Single nucleotide polymorphism; STR: Short tandem repeats; TET: Ten-eleven translocation proteins; WGA: Whole genome amplification

\section{Acknowledgements}

I sincerely thank State Forensic Science Laboratory Jharkhand as well as Department of Police, State Government of Jharkhand, India for its support in bringing out this review at the State Forensic Science Laboratory

Jharkhand, Ranchi, India.

Availability of data and materials

Not Required

Funding

None.

Author's contributions

AKR is the sole author and contributor of this review article.

Ethics approval and consent to participate

Not Required - This is a review article.

Consent for publication

Not Required - This is a review article.

\section{Competing interests}

The author (Rana, A.K.) certify that there is no academic or financial interest accrued to anyone and no other conflicts of interest exists whatsoever.

\section{Publisher's Note}

Springer Nature remains neutral with regard to jurisdictional claims in published maps and institutional affiliations.

Received: 5 September 2017 Accepted: 12 January 2018

Published online: 24 January 2018

References

Aberg KA, McClay JL, Nerella S, Xie LY, Clark SL, Hudson AD, Bukszar J, Adkins D, Consortium SS, Hultman CM, Sullivan PF, Magnusson PK, van den Oord EJ

(2012) MBD-seq as a cost-effective approach for methylome-wide association studies: demonstration in 1500 case-control samples. Epigenomics 4:605-621

Adkins RM, Krushkal J, Tylavsky FA, Thomas F (2011) Racial differences in genespecific DNA methylation levels are present at birth. Birth Defects Res A Clin Mol Teratol 91:728-736

An JH, Shin KJ, Yang WI, Lee HY (2012) Body fluid identification in forensics. BMB Rep 45:545-553

Antunes J, Silva DS, Balamurugan K, Duncan G, Alho CS, McCord B (2016) Forensic discrimination of vaginal epithelia by DNA methylation analysis through pyrosequencing. Electrophoresis 37:2751-2758

Auclair G, Weber M (2012) Mechanisms of DNA methylation and demethylation in mammals. Biochimie 94:2202-2211

Barres R, Osler ME, Yan J, Rune A, Fritz T, Caidahl K, Krook A, Zierath JR (2009) Non-CpG methylation of the PGC-1alpha promoter through DNMT3B controls mitochondrial density. Cell Metab 10:189-198

Barta JL, Monroe C, Crockford SJ, Kemp BM (2014) Mitochondrial DNA preservation across 3000-year-old northern fur seal ribs is not related to bone density: Implications for forensic investigations. Forensic Sci Int 239:11-18

Bekaert B, Kamalandua A, Zapico SC, Van de Voorde W, Decorte R (2015) Improved age determination of blood and teeth samples using a selected set of DNA methylation markers. Epigenetics 10:922-930

Bell JT, Loomis AK, Butcher LM, Gao F, Zhang B, Hyde CL, Sun J, Wu H, Ward K, Harris J, Scollen S, Davies MN, Schalkwyk LC, Mill J, Williams FM, Li N, Deloukas P, Beck S, SB MM, Wang J, John SL, Spector TD (2014) Differential methylation of the TRPA1 promoter in pain sensitivity. Nat Commun 5:2978 
Bellizzi D, D'Aquila P, Scafone T, Giordano M, Riso V, Riccio A, Passarino G (2013) The control region of mitochondrial DNA shows an unusual $\mathrm{CpG}$ and nonCpG methylation pattern. DNA Res 20:537-547

Benton MC, Johnstone A, Eccles D, Harmon B, Hayes MT, Lea RA, Griffiths L, Hoffman EP, Stubbs RS, Macartney-Coxson D (2015) An analysis of DNA methylation in human adipose tissue reveals differential modification of obesity genes before and after gastric bypass and weight loss. Genome Biol 16:8

Bibikova M, Barnes B, Tsan C, Ho V, Klotzle B, Le JM, Delano D, Zhang L, Schroth GP, Gunderson KL, Fan JB, Shen R (2011) High density DNA methylation array with single CpG site resolution. Genomics 98:288-295

Bocklandt S, Lin W, Sehl ME, Sanchez FJ, Sinsheimer JS, Horvath S, Vilain E (2011) Epigenetic predictor of age. PLoS One 6:e14821

Borgel J, Guibert S, Weber M (2012) Methylated DNA immunoprecipitation (MeDIP) from low amounts of cells. Methods Mol Biol 925:149-158

Bouwland-Both MI, van Mil NH, Tolhoek CP, Stolk L, Eilers PH, Verbiest MM, Heijmans BT, Uitterlinden AG, Hofman A, van ljzendoorn MH, Duijts $L$, de Jongste JC, Tiemeier H, Steegers EA, Jaddoe WW, Steegers-Theunissen RP (2015) Prenatal parental tobacco smoking, gene specific DNA methylation, and newborns size: the Generation R study. Clin Epigenetics 7(83)

Boyd VL, Zon G (2008) Capillary electrophoretic analysis of methylation status in CpG-rich regions by single-base extension of primers modified with N6methoxy-2,6-diaminopurine. Anal Biochem 380:13-20

Breitling LP, Yang R, Korn B, Burwinkel B, Brenner H (2011) Tobacco-smoking related differential DNA methylation: $27 \mathrm{~K}$ discovery and replication. Am J Hum Genet 88:450-457

Brena RM, Auer H, Kornacker K, Plass C (2006) Quantification of DNA methylation in electrofluidics chips (Bio-COBRA). Nat Protoc 1:52-58

Brena RM, Plass C (2009) Bio-COBRA: absolute quantification of DNA methylation in electrofluidics chips. Methods Mol Biol 507:257-269

Brunner AL, Johnson DS, Kim SW, Valouev A, Reddy TE, Neff NF, Anton E, Medina C, Nguyen L, Chiao E, Oyolu CB, Schroth GP, Absher DM, Baker JC, Myers RM (2009) Distinct DNA methylation patterns characterize differentiated human embryonic stem cells and developing human fetal liver. Genome Res 19:1044-1056

Bundo M, Sunaga F, Ueda J, Kasai K, Kato T, Iwamoto K (2012) A systematic evaluation of whole genome amplification of bisulfite-modified DNA. Clin Epigenetics 4:22

Carey G, Gottesman II (2006) Genes and antisocial behavior: perceived versus real threats to jurisprudence. J Law Med Ethics 34:342-351

Casadesus J, Low D (2006) Epigenetic gene regulation in the bacterial world. Microbiol Mol Biol Rev 70:830-856

Castillo-Fernandez JE, Spector TD, Bell JT (2014) Epigenetics of discordant monozygotic twins: implications for disease. Genome Med 6:60

Chatterjee A, Morison IM (2011) Monozygotic twins: genes are not the destiny? Bioinformation 7:369-370

Chen JW, Uboh CE, Soma LR, Li X, Guan F, You Y, Liu Y (2010) Identification of racehorse and sample contamination by novel 24-plex STR system. Forensic Sci Int Genet 4:158-167

Cheng Y, Yan Z, Liu Y, Liang C, Xia H, Feng J, Zheng G, Luo H (2014) Analysis of DNA methylation patterns associated with the gastric cancer genome. Oncol Lett 7:1021-1026

Cheung HH, Lee TL, Rennert OM, Chan WY (2011) Methylation profiling using methylated DNA immunoprecipitation and tiling array hybridization. Methods Mol Biol 825:115-126

Choufani S, Shapiro JS, Susiarjo M, Butcher DT, Grafodatskaya D, Lou Y, Ferreira JC, Pinto D, Scherer SW, Shaffer LG, Coullin P, Caniggia I, Beyene J, Slim R, Bartolomei MS, Weksberg R (2011) A novel approach identifies new differentially methylated regions (DMRs) associated with imprinted genes. Genome Res 21:465-476

Clement G, Benhattar J (2005) A methylation sensitive dot blot assay (MS-DBA) for the quantitative analysis of DNA methylation in clinical samples. J Clin Pathol 58:155-158

Coble MD, Just RS, O'Callaghan JE, Letmanyi IH, Peterson CT, Irwin JA, Parsons TJ (2004) Single nucleotide polymorphisms over the entire mtDNA genome that increase the power of forensic testing in Caucasians. Int J Legal Med 118:137-146

Darst RP, Pardo CE, Ai L, Brown KD, Kladde MP. Bisulfite sequencing of DNA. Curr Protoc Mol Biol 2010; Chapter 7 : Unit 7 1-17.

Day JJ, Sweatt JD (2010) DNA methylation and memory formation. Nat Neurosci 13:1319-1323

Deaton AM, Bird A (2011) CpG islands and the regulation of transcription. Genes Dev 25:1010-1022
Dinwiddie SH (1996) Genetics, antisocial personality, and criminal responsibility. Bull Am Acad Psychiatry Law 24:95-108

Eads CA, Danenberg KD, Kawakami K, Saltz LB, Blake C, Shibata D, Danenberg PV, Laird PW (2000) MethyLight: a high-throughput assay to measure DNA methylation. Nucleic Acids Res 28:E32

Eipel M, Mayer F, Arent T, Ferreira MR, Birkhofer C, Gerstenmaier U, Costa IG, RitzTimme S, Wagner W (2016) Epigenetic age predictions based on buccal swabs are more precise in combination with cell type-specific DNA methylation signatures. Aging (Albany NY) 8:1034-1048

Elboudwarej E, Cole M, Briggs FB, Fouts A, Fain PR, Quach H, Quach D, Sinclair E, Criswell LA, Lane JA, Steck AK, Barcellos LF, Noble JA (2016) Hypomethylation within gene promoter regions and type 1 diabetes in discordant monozygotic twins. J Autoimmun 68:23-29

Elliott HR, Tillin T, McArdle WL, Ho K, Duggirala A, Frayling TM, Davey Smith G, Hughes AD, Chaturvedi N, Relton CL (2014) Differences in smoking associated DNA methylation patterns in South Asians and Europeans. Clin Epigenetics 6:4

Forat S, Huettel B, Reinhardt R, Fimmers R, Haidl G, Denschlag D, Olek K (2016) Methylation Markers for the Identification of Body Fluids and Tissues from Forensic Trace Evidence. PLoS One 11:e0147973

Fouse SD, Nagarajan RO, Costello JF (2010) Genome-scale DNA methylation analysis. Epigenomics 2:105-117

Fraga MF, Ballestar E, Montoya G, Taysavang P, Wade PA, Esteller M (2003) The affinity of different MBD proteins for a specific methylated locus depends on their intrinsic binding properties. Nucleic Acids Res 31:1765-1774

Fraga MF, Ballestar E, Paz MF, Ropero S, Setien F, Ballestar ML, Heine-Suner D, Cigudosa JC, Urioste M, Benitez J, Boix-Chornet M, Sanchez-Aguilera A, Ling C, Carlsson E, Poulsen P, Vaag A, Stephan Z, Spector TD, Wu YZ, Plass C, Esteller M (2005) Epigenetic differences arise during the lifetime of monozygotic twins. Proc Natl Acad Sci U S A 102:10604-10609

Fraser HB, Lam LL, Neumann SM, Kobor MS (2012) Population-specificity of human DNA methylation. Genome Biol 13:R8

Freire-Aradas A, Phillips C, Mosquera-Miguel A, Giron-Santamaria L, Gomez-Tato A, Casares de Cal M, Alvarez-Dios J, Ansede-Bermejo J, Torres-Espanol M, Schneider PM, Pospiech E, Branicki W, Carracedo A, Lareu MV (2016) Development of a methylation marker set for forensic age estimation using analysis of public methylation data and the Agena Bioscience EpiTYPER system. Forensic Sci Int Genet 24:65-74

Frumkin D, Wasserstrom A, Budowle B, Davidson A (2011) DNA methylationbased forensic tissue identification. Forensic Sci Int Genet 5:517-524

Frumkin D, Wasserstrom A, Davidson A, Grafit A (2010) Authentication of forensic DNA samples. Forensic Sci Int Genet 4:95-103

Garagnani P, Bacalini MG, Pirazzini C, Gori D, Giuliani C, Mari D, Di Blasio AM, Gentilini D, Vitale G, Collino S, Rezzi S, Castellani G, Capri M, Salvioli S, Franceschi C (2012) Methylation of ELOVL2 gene as a new epigenetic marker of age. Aging Cell 11:1132-1134

Giuliani C, Cilli E, Bacalini MG, Pirazzini C, Sazzini M, Gruppioni G, Franceschi C, Garagnani P, Luiselli D (2015) Inferring chronological age from DNA methylation patterns of human teeth. Am J Phys Anthropol 159:585-595

Green RL, Lagace RE, Oldroyd NJ, Hennessy LK, Mulero JJ (2013) Developmental validation of the AmpFISTR(R) NGM SElect PCR Amplification Kit: A next-generation STR multiplex with the SE33 locus. Forensic Sci Int Genet 7:41-51

Grunau C, Renault E, Rosenthal A, Roizes G (2001) MethDB-a public database for DNA methylation data. Nucleic Acids Res 29:270-274

Gu H, Bock C, Mikkelsen TS, Jager N, Smith ZD, Tomazou E, Gnirke A, Lander ES, Meissner A (2010) Genome-scale DNA methylation mapping of clinical samples at single-nucleotide resolution. Nat Methods 7:133-136

Guo H, Zhu P, Yan L, Li R, Hu B, Lian Y, Yan J, Ren X, Lin S, Li J, Jin X, Shi X, Liu P, Wang X, Wang W, Wei Y, Li X, Guo F, Wu X, Fan X, Yong J, Wen L, Xie SX, Tang F, Qiao J (2014) The DNA methylation landscape of human early embryos. Nature 511:606-610

Hackenberg M, Barturen G, Oliver JL (2011) NGSmethDB: a database for nextgeneration sequencing single-cytosine-resolution DNA methylation data. Nucleic Acids Res 39:D75-D79

Hamano Y, Manabe S, Morimoto C, Fujimoto S, Ozeki M, Tamaki K (2016) Forensic age prediction for dead or living samples by use of methylationsensitive high resolution melting. Leg Med (Tokyo) 21:5-10

Hannum G, Guinney J, Zhao L, Zhang L, Hughes G, Sadda S, Klotzle B, Bibikova M, Fan JB, Gao Y, Deconde R, Chen M, Rajapakse I, Friend S, Ideker T, Zhang K (2012) Genome-wide methylation profiles reveal quantitative views of human aging rates. Mol Cell 49:359-367 
Harris RA, Wang T, Coarfa C, Nagarajan RP, Hong C, Downey SL, Johnson BE, Fouse SD, Delaney A, Zhao Y, Olshen A, Ballinger T, Zhou X, Forsberg KJ, Gu J, Echipare L, O'Geen H, Lister R, Pelizzola M, Xi Y, Epstein CB, Bernstein BE, Hawkins RD, Ren B, Chung WY, Gu H, Bock C, Gnirke A, Zhang MQ, Haussler D, Ecker JR, Li W, Farnham PJ, Waterland RA, Meissner A, Marra MA, Hirst M, Milosavljevic A, Costello JF (2010) Comparison of sequencing-based methods to profile DNA methylation and identification of monoallelic epigenetic modifications. Nat Biotechnol 28:1097-1105

Hart KL, Kimura SL, Mushailov V, Budimlija ZM, Prinz M, Wurmbach E (2013) Improved eye- and skin-color prediction based on 8 SNPs. Croat Med J 54:248-256

Hennessy LK, Mehendale N, Chear K, Jovanovich S, Williams S, Park C, Gangano S (2014) Developmental validation of the GlobalFiler((R)) express kit, a 24-marker STR assay, on the RapidHIT((R)) System. Forensic Sci Int Genet 13:247-258

Herman JG, Graff JR, Myohanen S, Nelkin BD, Baylin SB (1996) Methylationspecific PCR: a novel PCR assay for methylation status of $\mathrm{CpG}$ islands. Proc Natl Acad Sci U S A 93:9821-9826

Heyn H, Moran S, Hernando-Herraez I, Sayols S, Gomez A, Sandoval J, Monk D, Hata K, Marques-Bonet T, Wang L, Esteller M (2013) DNA methylation contributes to natural human variation. Genome Res 23:1363-1372

Higgins D, Rohrlach AB, Kaidonis J, Townsend G, Austin JJ (2015) Differential nuclear and mitochondrial DNA preservation in post-mortem teeth with implications for forensic and ancient DNA studies. PLoS One 10:e0126935

Horvath S (2013) DNA methylation age of human tissues and cell types. Genome Biol 14:R115

Hu J, Zhang CY (2012) Single base extension reaction-based surface enhanced Raman spectroscopy for DNA methylation assay. Biosens Bioelectron 31:451-457

Huang J, Renault V, Sengenes J, Touleimat N, Michel S, Lathrop M, Tost J (2012) MeQA: a pipeline for MeDIP-seq data quality assessment and analysis. Bioinformatics 28:587-588

Jaenisch R, Bird A (2003) Epigenetic regulation of gene expression: how the genome integrates intrinsic and environmental signals. Nat Genet 33(Suppl): $245-254$

Jeltsch A (2002) Beyond Watson and Crick: DNA methylation and molecular enzymology of DNA methyltransferases. Chembiochem 3:274-293

Jin B, Li Y, Robertson KD (2011) DNA methylation: superior or subordinate in the epigenetic hierarchy? Genes Cancer 2:607-617

Jones MJ, Goodman SJ, Kobor MS (2015) DNA methylation and healthy human aging. Aging Cell

Jung SE, Cho S, Antunes J, Gomes I, Uchimoto ML, Oh YN, Di Giacomo L, Schneider PM, Park MS, van der Meer D, Williams G, McCord B, Ahn HJ, Choi DH, Lee YH, Lee SD, Lee HY (2016) A collaborative exercise on DNA methylation based body fluid typing. Electrophoresis 37:2759-2766

Just RS, Leney MD, Barritt SM, Los CW, Smith BC, Holland TD, Parsons TJ (2009) The use of mitochondrial DNA single nucleotide polymorphisms to assist in the resolution of three challenging forensic cases. J Forensic Sci 54:887-891

Kader F, Ghai M (2016) DNA methylation-based variation between human populations. Mol Genet Genomics

Kalozoumi G, Tzimas C, Sanoudou D (2012) The expanding role of epigenetics. Glob Cardiol Sci Pract 2012:7

Kaminsky ZA, Tang T, Wang SC, Ptak C, Oh GH, Wong AH, Feldcamp LA, Virtanen C, Halfvarson J, Tysk C, McRae AF, Visscher PM, Montgomery GW, Gottesman II, Martin NG, Petronis A (2009) DNA methylation profiles in monozygotic and dizygotic twins. Nat Genet 41:240-245

Khulan B, Manning JR, Dunbar DR, Seckl JR, Raikkonen K, Eriksson JG, Drake AJ (2014) Epigenomic profiling of men exposed to early-life stress reveals DNA methylation differences in association with current mental state. Transl Psychiatry 4:e448

Khulan B, Thompson RF, Ye K, Fazzari MJ, Suzuki M, Stasiek E, Figueroa ME, Glass JL, Chen Q, Montagna C, Hatchwell E, Selzer RR, Richmond TA, Green RD, Melnick A, Greally JM (2006) Comparative isoschizomer profiling of cytosine methylation: the HELP assay. Genome Res 16:1046-1055

Kim D, Kubzansky LD, Baccarelli A, Sparrow D, Spiro A 3rd, Tarantini L, Cantone L, Vokonas P, Schwartz J (2016) Psychological factors and DNA methylation of genes related to immune/inflammatory system markers: the VA Normative Aging Study. BMJ Open 6:e009790

Koch CM, Wagner W (2011) Epigenetic-aging-signature to determine age in different tissues. Aging (Albany NY) 3:1018-1027

Kockler TR, Stanford MS, Nelson CE, Meloy JR, Sanford K (2006) Characterizing aggressive behavior in a forensic population. Am J Orthopsychiatry 76:80-85

Kovatsi L, Fragou D, Samanidou V, Njau S, Kouidou S (2011) Drugs of abuse: epigenetic mechanisms in toxicity and addiction. Curr Med Chem 18: $1765-1774$
Koziol MJ, Bradshaw CR, Allen GE, Costa AS, Frezza C, Gurdon JB (2016) Identification of methylated deoxyadenosines in vertebrates reveals diversity in DNA modifications. Nat Struct Mol Biol 23:24-30

Kristensen LS, Mikeska T, Krypuy M, Dobrovic A (2008) Sensitive Melting Analysis after Real Time- Methylation Specific PCR (SMART-MSP): high-throughput and probe-free quantitative DNA methylation detection. Nucleic Acids Res 36:e42

Lam LL, Emberly E, Fraser HB, Neumann SM, Chen E, Miller GE, Kobor MS (2012) Factors underlying variable DNA methylation in a human community cohort. Proc Natl Acad Sci U S A 109(Suppl 2):17253-17260

Lan X, Adams C, Landers M, Dudas M, Krissinger D, Marnellos G, Bonneville R, Xu M, Wang J, Huang TH, Meredith G, Jin VX (2011) High resolution detection and analysis of $\mathrm{CpG}$ dinucleotides methylation using MBD-Seq technology. PLoS One 6:e22226

Lee HY, Jung SE, Lee EH, Yang WI, Shin KJ (2016) DNA methylation profiling for a confirmatory test for blood, saliva, semen, vaginal fluid and menstrual blood. Forensic Sci Int Genet 24:75-82

Lee HY, Jung SE, Oh YN, Choi A, Yang WI, Shin KJ (2015) Epigenetic age signatures in the forensically relevant body fluid of semen: a preliminary study. Forensic Sci Int Genet 19:28-34

Lee HY, Park MJ, Choi A, An JH, Yang WI, Shin KJ (2012) Potential forensic application of DNA methylation profiling to body fluid identification. Int J Legal Med 126:55-62

Levesque ML, Casey KF, Szyf M, Ismaylova E, Ly V, Verner MP, Suderman M, Brendgen M, Vitaro F, Dionne G, Boivin M, Tremblay RE, Booij L (2014) Genome-wide DNA methylation variability in adolescent monozygotic twins followed since birth. Epigenetics 9:1410-1421

Li C, Zhao S, Zhang N, Zhang S, Hou Y (2013) Differences of DNA methylation profiles between monozygotic twins' blood samples. Mol Biol Rep 40:5275-5280

Lightowlers RN, Chinnery PF, Turnbull DM, Howell N (1997) Mammalian mitochondrial genetics: heredity, heteroplasmy and disease. Trends Genet 13:450-455

Lin YC, Tsai LC, Lee JC, Su CW, Tzen JT, Linacre A, Hsieh HM (2016) Novel identification of biofluids using a multiplex methylation sensitive restriction enzyme-PCR system. Forensic Sci Int Genet 25:157-165

Lister R, Ecker JR (2009) Finding the fifth base: genome-wide sequencing of cytosine methylation. Genome Res 19:959-966

Liu B, Du Q, Chen L, Fu G, Li S, Fu L, Zhang X, Ma C, Bin C (2016) CpG methylation patterns of human mitochondrial DNA. Sci Rep 6(23421)

Liu F, Visser M, Duffy DL, Hysi PG, Jacobs LC, Lao O, Zhong K, Walsh S, Chaitanya L, Wollstein A, Zhu G, Montgomery GW, Henders AK, Mangino M, Glass D, Bataille V, Sturm RA, Rivadeneira F, Hofman A, van IWF, Uitterlinden AG, Palstra RJ, Spector TD, Martin NG, Nijsten TE, Kayser M (2015) Genetics of skin color variation in Europeans: genome-wide association studies with functional follow-up. Hum Genet 134:823-835

Lo PK, Watanabe H, Cheng PC, Teo WW, Liang X, Argani P, Lee JS, Sukumar S (2009) MethySYBR, a novel quantitative PCR assay for the dual analysis of DNA methylation and CpG methylation density. J Mol Diagn 11:400-414

Lokk K, Modhukur V, Rajashekar B, Martens K, Magi R, Kolde R, Koltsina M, Nilsson TK, Vilo J, Salumets A, Tonisson N (2014) DNA methylome profiling of human tissues identifies global and tissue-specific methylation patterns. Genome Biol 15:r54

Low DA, Weyand NJ, Mahan MJ (2001) Roles of DNA adenine methylation in regulating bacterial gene expression and virulence. Infect Immun 69:7197-7204

Madi T, Balamurugan K, Bombardi R, Duncan G, McCord B The determination of tissue-specific DNA methylation patterns in forensic biofluids using bisulfite modification and pyrosequencing. Electrophoresis 33:1736-1745

Marcinska M, Pospiech E, Abidi S, Andersen JD, van den Berge M, Carracedo A, Eduardoff M, Marczakiewicz-Lustig A, Morling N, Sijen T, Skowron M, Sochtig J, Syndercombe-Court D, Weiler N, Schneider PM, Ballard D, Borsting C, Parson W, Phillips C, Branicki W (2015) Evaluation of DNA variants associated with androgenetic alopecia and their potential to predict male pattern baldness. PLoS One 10:e0127852

Mardis ER (2013) Next-generation sequencing platforms. Annu Rev Anal Chem (Palo Alto Calif) 6:287-303

Marjonen H, Sierra A, Nyman A, Rogojin V, Grohn O, Linden AM, Hautaniemi S, Kaminen-Ahola N (2015) Early maternal alcohol consumption alters hippocampal DNA methylation, gene expression and volume in a mouse model. PLoS One 10:e0124931

Marsit CJ (2015) Influence of environmental exposure on human epigenetic regulation. J Exp Biol 218:71-79

Masemola ML, van der Merwe L, Lombard Z, Viljoen D, Ramsay M (2015) Reduced DNA methylation at the PEG3 DMR and KvDMR1 loci in children exposed to alcohol in utero: a South African Fetal Alcohol Syndrome cohort study. Front Genet 6(85) 
Masser DR, Stanford DR, Freeman WM (2015) Targeted DNA methylation analysis by next-generation sequencing. J Vis Exp

McCartney DL, Walker RM, Morris SW, AM MI, Porteous DJ, Evans KL (2016) Identification of polymorphic and off-target probe binding sites on the Illumina Infinium MethylationEPIC BeadChip. Genom Data 9:22-24

Meaney MJ, Szyf M (2005) Environmental programming of stress responses through DNA methylation: life at the interface between a dynamic environment and a fixed genome. Dialogues Clin Neurosci 7:103-123

Mednick SA, Finello KM (1983) Biological factors and crime: implications for forensic psychiatry. Int J Law Psychiatry 6:1-15

Melchior L, Kivisild T, Lynnerup N, Dissing J (2008) Evidence of authentic DNA from Danish Viking Age skeletons untouched by humans for 1,000 years. PLoS One 3:e2214

Mitchell JA, Grant SF (2015) Ethnic disparities in DNA methylation and risk of type 2 diabetes. Lancet Diabetes Endocrinol

Mohn F, Weber M, Schubeler D, Roloff TC (2009) Methylated DNA immunoprecipitation (MeDIP). Methods Mol Biol 507:55-64

Monick MM, Beach SR, Plume J, Sears R, Gerrard M, Brody GH, Philibert RA (2012) Coordinated changes in AHRR methylation in lymphoblasts and pulmonary macrophages from smokers. Am J Med Genet B Neuropsychiatr Genet 159B: $141-151$

Moore LD, Le T, Fan G (2013) DNA methylation and its basic function. Neuropsychopharmacology 38:23-38

Moran S, Arribas C, Esteller M (2016) Validation of a DNA methylation microarray for $850,000 \mathrm{CpG}$ sites of the human genome enriched in enhancer sequences. Epigenomics 8:389-399

Mulero JJ, Chang CW, Lagace RE, Wang DY, Bas JL, McMahon TP, Hennessy LK (2008) Development and validation of the AmpFISTR MiniFiler PCR Amplification Kit: a MiniSTR multiplex for the analysis of degraded and/or PCR inhibited DNA. J Forensic Sci 53:838-852

Nesheva D (2015) Aspects of ancient mitochondrial DNA analysis in different populations for understanding human evolution. Balkan J Med Genet 17:5-14

Numata S, Ye T, Hyde TM, Guitart-Navarro X, Tao R, Wininger M, Colantuoni C, Weinberger DR, Kleinman JE, Lipska BK (2012) DNA methylation signatures in development and aging of the human prefrontal cortex. Am J Hum Genet 90:260-272

Oda M, Greally JM (2009) The HELP assay. Methods Mol Biol 507:77-87

Oostdik K, Lenz K, Nye J, Schelling K, Yet D, Bruski S, Strong J, Buchanan C, Sutton J, Linner J, Frazier N, Young H, Matthies L, Sage A, Hahn J, Wells R, Williams N, Price M, Koehler J, Staples M, Swango KL, Hill C, Oyerly K, Duke W, Katzilierakis L, Ensenberger MG, Bourdeau JM, Sprecher CJ, Krenke B, Storts DR (2014) Developmental validation of the PowerPlex((R)) Fusion System for analysis of casework and reference samples: A 24-locus multiplex for new database standards. Forensic Sci Int Genet 12:69-76

Ozga AT, Nieves-Colon MA, Honap TP, Sankaranarayanan K, Hofman CA, Milner GR, Lewis CM Jr, Stone AC, Warinner C (2016) Successful enrichment and recovery of whole mitochondrial genomes from ancient human dental calculus. Am J Phys Anthropol 160:220-228

Park JL, Kim JH, Seo E, Bae DH, Kim SY, Lee HC, Woo KM, Kim YS (2016) Identification and evaluation of age-correlated DNA methylation markers for forensic use. Forensic Sci Int Genet 23:64-70

Park JL, Kwon OH, Kim JH, Yoo HS, Lee HC, Woo KM, Kim SY, Lee SH, Kim YS (2014) Identification of body fluid-specific DNA methylation markers for use in forensic science. Forensic Sci Int Genet 13:147-153

Pelizzola M, Molinaro A (2011) Methylated DNA immunoprecipitation genomewide analysis. Methods Mol Biol 791:113-123

Philibert RA, Plume JM, Gibbons FX, Brody GH, Beach SR (2012) The impact of recent alcohol use on genome wide DNA methylation signatures. Front Genet 3:54

Pidsley R, Zotenko E, Peters TJ, Lawrence MG, Risbridger GP, Molloy P, Van Djik S, Muhlhausler B, Stirzaker C, Clark SJ (2016) Critical evaluation of the Illumina MethylationEPIC BeadChip microarray for whole-genome DNA methylation profiling. Genome Biol 17:208

Pospiech E, Karlowska-Pik J, Marcinska M, Abidi S, Andersen JD, van den Berge M, Carracedo A, Eduardoff M, Freire-Aradas A, Morling N, Sijen T, Skowron M, Sochtig J, Syndercombe-Court D, Weiler N, Schneider PM, Ballard D, Borsting C, Parson W, Phillips C, Branicki W (2015) Evaluation of the predictive capacity of DNA variants associated with straight hair in Europeans. Forensic Sci Int Genet 19:280-288

Provencal N, Suderman MJ, Guillemin C, Vitaro F, Cote SM, Hallett M, Tremblay RE, Szyf M (2014) Association of childhood chronic physical aggression with a DNA methylation signature in adult human T cells. PLoS One 9:e89839
Race E, Genetics Working Group (2005) The use of racial, ethnic, and ancestral categories in human genetics research. Am J Hum Genet 77:519-532

Rakyan VK, Down TA, Maslau S, Andrew T, Yang TP, Beyan H, Whittaker P, McCann OT, Finer S, Valdes AM, Leslie RD, Deloukas P, Spector TD (2010) Human aging-associated DNA hypermethylation occurs preferentially at bivalent chromatin domains. Genome Res 20:434-439

Rana AK, Kumar N, Imam J, Sinha MK, Sinha HK, Singh R (2016) Challenging and Rare DNA Evidences Convicts the Accused in a High Profile Murder Case. Austin Journal of Forensic Science and Criminology 3:1046

Rand K, Qu W, Ho T, Clark SJ, Molloy P (2002) Conversion-specific detection of DNA methylation using real-time polymerase chain reaction (ConLight-MSP) to avoid false positives. Methods 27:114-120

Ratel D, Ravanat JL, Berger F, Wion D (2006) N6-methyladenine: the other methylated base of DNA. Bioessays 28:309-315

Rauch T, Pfeifer GP (2005) Methylated-CpG island recovery assay: a new technique for the rapid detection of methylated-CpG islands in cancer. Lab Invest 85:1172-1180

Ribel-Madsen R, Fraga MF, Jacobsen S, Bork-Jensen J, Lara E, Calvanese V, Fernandez AF, Friedrichsen M, Vind BF, Hojlund K, Beck-Nielsen H, Esteller M, Vaag A, Poulsen P (2012) Genome-wide analysis of DNA methylation differences in muscle and fat from monozygotic twins discordant for type 2 diabetes. PLoS One 7:e51302

Richards EJ (2006) Inherited epigenetic variation-revisiting soft inheritance. Nat Rev Genet 7:395-401

Roos L, van Dongen J, Bell CG, Burri A, Deloukas P, Boomsma DI, Spector TD, Bell JT (2016) Integrative DNA methylome analysis of pan-cancer biomarkers in cancer discordant monozygotic twin-pairs. Clin Epigenetics 8:7

Roth TL, Sweatt JD (2010) Annual Research Review: Epigenetic mechanisms and environmental shaping of the brain during sensitive periods of development. J Child Psychol Psychiatry 52:398-408

Royal CD, Novembre J, Fullerton SM, Goldstein DB, Long JC, Bamshad MJ, Clark AG (2010) Inferring genetic ancestry: opportunities, challenges, and implications. Am J Hum Genet 86:661-673

Sanger F, Air GM, Barrell BG, Brown NL, Coulson AR, Fiddes CA, Hutchison CA, Slocombe PM, Smith M (1977) Nucleotide sequence of bacteriophage phi X174 DNA. Nature 265:687-695

Schumacher A, Kapranov P, Kaminsky Z, Flanagan J, Assadzadeh A, Yau P, Virtanen C, Winegarden N, Cheng J, Gingeras T, Petronis A (2006) Microarraybased DNA methylation profiling: technology and applications. Nucleic Acids Res 34:528-542

Schwarz C, Debruyne R, Kuch M, McNally E, Schwarcz H, Aubrey AD, Bada J, Poinar $H$ (2009) New insights from old bones: DNA preservation and degradation in permafrost preserved mammoth remains. Nucleic Acids Res 37:3215-3229

Segal NL, Montoya YS, Loke YJ, Craig JM (2016) Identical twins doubly exchanged at birth: a case report of genetic and environmental influences on the adult epigenome. Epigenomics

Shaknovich R, Figueroa ME, Melnick A (2010) HELP (Hpall tiny fragment enrichment by ligation-mediated $P(R)$ assay for DNA methylation profiling of primary normal and malignant B lymphocytes. Methods Mol Biol 632:191-201

Shareck M, Ellaway A (2011) Neighbourhood crime and smoking: the role of objective and perceived crime measures. BMC Public Health 11(930)

Shenker NS, Polidoro S, van Veldhoven K, Sacerdote C, Ricceri F, Birrell MA, Belvisi MG, Brown R, Vineis P, Flanagan JM (2013) Epigenome-wide association study in the European Prospective Investigation into Cancer and Nutrition (EPIC-Turin) identifies novel genetic loci associated with smoking. Hum Mol Genet 22:843-851

Smith AK, Kilaru V, Klengel T, Mercer KB, Bradley B, Conneely KN, Ressler KJ, Binder EB (2014) DNA extracted from saliva for methylation studies of psychiatric traits: evidence tissue specificity and relatedness to brain. Am J Med Genet B Neuropsychiatr Genet 168B:36-44

Sorensen AL, Collas P (2009) Immunoprecipitation of methylated DNA. Methods Mol Biol 567:249-262

Souren NY, Lutsik P, Gasparoni G, Tierling S, Gries J, Riemenschneider M, Fryns JP, Derom C, Zeegers MP, Walter J (2013) Adult monozygotic twins discordant for intra-uterine growth have indistinguishable genome-wide DNA methylation profiles. Genome Biol 14:R44

Staunstrup NH, Starnawska A, Nyegaard M, Christiansen L, Nielsen AL, Borglum A, Mors O (2016) Genome-wide DNA methylation profiling with MeDIP-seq using archived dried blood spots. Clin Epigenetics 8(81)

Stewart L, Evans N, Bexon KJ, van der Meer DJ, Williams GA (2015) Differentiating between monozygotic twins through DNA methylation-specific highresolution melt curve analysis. Anal Biochem 476:36-39 
Strachan T, Read A (2011) Human Molecular Genetics. 4th Editon. Garland Science, Taylor \& Francis Group, LLC, New York

Szulik MW, Pallan PS, Nocek B, Voehler M, Banerjee S, Brooks S, Joachimiak A, Egli M, Eichman BF, Stone MP (2015) Differential stabilities and sequencedependent base pair opening dynamics of Watson-Crick base pairs with 5-hydroxymethylcytosine, 5-formylcytosine, or 5-carboxylcytosine. Biochemistry 54:1294-1305

Szyf M (2011) DNA methylation, the early-life social environment and behavioral disorders. J Neurodev Disord 3:238-249

Szyf M (2013) DNA methylation, behavior and early life adversity. J Genet Genomics 40:331-338

Taiwo O, Wilson GA, Morris T, Seisenberger S, Reik W, Pearce D, Beck S, Butcher LM (2012) Methylome analysis using MeDIP-seq with low DNA concentrations. Nat Protoc 7:617-636

Tamatea AJ (2015) 'Biologizing' Psychopathy: Ethical, Legal, and Research Implications at the Interface of Epigenetics and Chronic Antisocial Conduct. Behav Sci Law 33:629-643

Thompson TM, Sharfi D, Lee M, Yrigollen CM, Naumova OY, Grigorenko EL (2012) Comparison of whole-genome DNA methylation patterns in whole blood, saliva, and lymphoblastoid cell lines. Behav Genet 43:168-176

Tost J, Gut IG (2007) DNA methylation analysis by pyrosequencing. Nat Protoc 2: $2265-2275$

Touleimat N, Tost J (2012) Complete pipeline for Infinium((R)) Human Methylation 450K BeadChip data processing using subset quantile normalization for accurate DNA methylation estimation. Epigenomics 4:325-341

Triche TJ Jr, Weisenberger DJ, Van Den Berg D, Laird PW, Siegmund KD (2013) Low-level processing of Illumina Infinium DNA Methylation BeadArrays. Nucleic Acids Res 41:e90

Unternaehrer E, Luers P, Mill J, Dempster E, Meyer AH, Staehli S, Lieb R, Hellhammer DH, Meinlschmidt G (2012) Dynamic changes in DNA methylation of stress-associated genes (OXTR, BDNF ) after acute psychosocial stress. Transl Psychiatry 2:e150

Vanyushin BF, Kirnos MD (1977) The structure of animal mitochondrial DNA (base composition, pyrimidine clusters, character of methylation). Mol Cell Biochem 14:31-36

Vidaki A, Giangasparo F, Syndercombe Court D (2016) Discovery of potential DNA methylation markers for forensic tissue identification using bisulphite pyrosequencing. Electrophoresis 37:2767-2779

Walsh S, Liu F, Wollstein A, Kovatsi L, Ralf A, Kosiniak-Kamysz A, Branicki W, Kayser M (2013) The HirisPlex system for simultaneous prediction of hair and eye colour from DNA. Forensic Sci Int Genet 7:98-115

Wang DY, Chang CW, Lagace RE, Calandro LM, Hennessy LK (2012) Developmental validation of the AmpFISTR(R) Identifiler(R) Plus PCR Amplification Kit: an established multiplex assay with improved performance. J Forensic Sci 57:453-465

Watanabe M, Honda C, Iwatani Y, Yorifuji S, Iso H, Kamide K, Hatazawa J, Kihara S, Sakai N, Watanabe H, Makimoto K (2016) Within-pair differences of DNA methylation levels between monozygotic twins are different between male and female pairs. BMC Med Genomics 9:55

Weber-Lehmann J, Schilling E, Gradl G, Richter DC, Wiehler J, Rolf B (2014) Finding the needle in the haystack: differentiating "identical" twins in paternity testing and forensics by ultra-deep next generation sequencing. Forensic Sci Int Genet 9:42-46

Weidner Cl, Lin Q, Koch CM, Eisele L, Beier F, Ziegler P, Bauerschlag DO, Jockel KH, Erbel R, Muhleisen TW, Zenke M, Brummendorf TH, Wagner W (2014) Aging of blood can be tracked by DNA methylation changes at just three CpG sites. Genome Biol 15:R24

Wilson GG, Murray NE (1991) Restriction and modification systems. Annu Rev Genet 25:585-627

Wnuk M, Lewinska A, Gurgul A, Zabek T, Potocki L, Oklejewicz B, BugnoPoniewierska M, Wegrzyn M, Slota E (2013) Changes in DNA methylation patterns and repetitive sequences in blood lymphocytes of aged horses. Age (Dordr) 36:31-48

Wojdacz TK, Dobrovic A (2009) Melting curve assays for DNA methylation analysis. Methods Mol Biol 507:229-240

Wong CC, Caspi A, Williams B, Craig IW, Houts R, Ambler A, Moffitt TE, Mill J (2010) A longitudinal study of epigenetic variation in twins. Epigenetics 5: 516-526

Wu Y, Patchev AV, Daniel G, Almeida OF, Spengler D (2014) Early-life stress reduces DNA methylation of the Pomc gene in male mice. Endocrinology $155: 1751-1762$
Xia YY, Ding YB, Liu XQ, Chen XM, Cheng SQ, Li LB, Ma MF, He JL, Wang YX (1846) Racial/ethnic disparities in human DNA methylation. Biochim Biophys Acta 2014:258-262

Xiong Z, Laird PW (1997) COBRA: a sensitive and quantitative DNA methylation assay. Nucleic Acids Res 25:2532-2534

Yan PS, Chen CM, Shi H, Rahmatpanah F, Wei SH, Huang TH (2002) Applications of CpG island microarrays for high-throughput analysis of DNA methylation. J Nutr 132:2430S-2434S

Yang CH, Chuang LY, Cheng YH, Gu DL, Chen CH, Chang HW (2010) MethylTyping: an improved and visualized COBRA software for epigenomic studies. FEBS Lett 584:739-744

Yi SH, Jia YS, Mei K, Yang RZ, Huang DX (2015) Age-related DNA methylation changes for forensic age-prediction. Int J Legal Med 129:237-244

Zbiec-Piekarska R, Spolnicka M, Kupiec T, Makowska Z, Spas A, Parys-Proszek A, Kucharczyk K, Ploski R, Branicki W (2014) Examination of DNA methylation status of the ELOVL2 marker may be useful for human age prediction in forensic science. Forensic Sci Int Genet 14:161-167

Zeilinger S, Kuhnel B, Klopp N, Baurecht H, Kleinschmidt A, Gieger C, Weidinger S, Lattka E, Adamski J, Peters A, Strauch K, Waldenberger M, Illig T (2013) Tobacco smoking leads to extensive genome-wide changes in DNA methylation. PLoS One 8:e63812

Zhang B, Zhou Y, Lin N, Lowdon RF, Hong C, Nagarajan RP, Cheng JB, Li D, Stevens $M$, Lee HJ, Xing X, Zhou J, Sundaram V, Elliott G, Gu J, Shi T, Gascard P, Sigaroudinia M, Tlsty TD, Kadlecek T, Weiss A, O'Geen H, Farnham PJ, Maire CL, Ligon KL, Madden PA, Tam A, Moore R, Hirst M, Marra MA, Costello JF, Wang T (2013) Functional DNA methylation differences between tissues, cell types, and across individuals discovered using the M\&M algorithm. Genome Res 23:1522-1540

Zhang H, Herman Al, Kranzler HR, Anton RF, Zhao H, Zheng W, Gelernter J (2012) Array-based profiling of DNA methylation changes associated with alcohol dependence. Alcohol Clin Exp Res 37(Suppl 1):E108-E115

Zhao J, Goldberg J, Vaccarino V (2011) Promoter methylation of serotonin transporter gene is associated with obesity measures: a monozygotic twin study. Int J Obes (Lond) 37:140-145

Zhao MT, Whyte JJ, Hopkins GM, Kirk MD, Prather RS (2014) Methylated DNA immunoprecipitation and high-throughput sequencing (MeDIP-seq) using low amounts of genomic DNA. Cell Reprogram 16:175-184

Zykovich A, Hubbard A, Flynn JM, Tarnopolsky M, Fraga MF, Kerksick C, Ogborn D, MacNeil L, Mooney SD, Melov S (2013) Genome-wide DNA methylation changes with age in disease-free human skeletal muscle. Aging Cell 13:360-366

\section{Submit your manuscript to a SpringerOpen ${ }^{\mathcal{O}}$ journal and benefit from:}

- Convenient online submission

- Rigorous peer review

- Open access: articles freely available online

- High visibility within the field

- Retaining the copyright to your article

Submit your next manuscript at $>$ springeropen.com 